\title{
A 2,500-year multi-proxy reconstruction of climate change and human activities in northern Spain: the Lake Arreo record
}

Juan Pablo Corella ${ }^{1,2 *}$, Vania Stefanova ${ }^{3}$, Adel El Anjoumi ${ }^{4}$, Eugenio Rico $^{4}$, Santiago Giralt ${ }^{5}$, Ana Moreno ${ }^{1}$, Alberto Plata-Montero ${ }^{6}$ and Blas L. Valero-Garcés ${ }^{1}$

${ }^{1}$ Instituto Pirenaico de Ecología (IPE-CSIC), Avda Montañana 1005, 50059 Zaragoza, Spain. E-mail addresses: blas@ipe.csic.es, amoreno@ipe.csic.es,

${ }^{2}$ Museo Nacional de Ciencias Naturales (MNCN-CSIC), C/ Serrano 112bis, 28006

Madrid, Spain. E-mail address: pablo.corella@mncn.csic.es

${ }^{3}$ Limnological Research Center, University of Minnesota, Minneapolis, MN-55455.

USA. E-mail address: stefa014@umn.edu

${ }^{4}$ Universidad Autónoma de Madrid, Department of Ecology, c/Darwin 2, 28049 Madrid.

Spain. E-mail addresses: adel.amrani@uam.es, eugenio.rico@uam.es

${ }^{5}$ Institute of Earth Sciences Jaume Almera (ICTJA-CSIC), C/ Lluís Solé i Sabarís s/n,

08028 Barcelona. Spain. . E-mail address: sgiralt@ictja.csic.es

${ }^{6}$ Fundación Valle Salado de Añana, plaza Miguel Díaz de Tuesta, 01426 Salinas de Añana.

Spain. E-mail address: alberto@vallesalado.com

(*) Corresponding author:

e-mail:pablo.corella@mncn.csic.es

Telephone: +34917452500 ext. 980603

Fax: +34 915640800 


\section{ABSTRACT}

Lake Arreo sequence (western Ebro Basin, Spain) illustrates the century-scale climatic variability and human interactions in the landscape during the last $2.5 \mathrm{kyr}$ in the low lands of northern Spain. Two sediment cores from shallow-water and deep-water environments were analyzed using sedimentological, geochemical, mineralogical, biological -diatoms, pollen and charcoal content-, and radiometric techniques for absolute dating. The shallow-water sequence indicates a rapid evolution from an alluvial-influenced wetland prior to $7^{\text {th }}$ century BC to a wetland during the Ibero-Roman Humid Period (BC 630 - AD 465) and a deeper, carbonate producing lake during the Dark Ages Cold Period (AD 465-890). The deep-water core shows the transition from a more saline lake during the arid Medieval Climate Anomaly (MCA, AD 890-1300) to less saline, meromictic conditions, particularly since the onset of the Little Ice Age (LIA, AD 1300-1870). During the last $2.5 \mathrm{kyr}$, arid conditions occurred prior to $1^{\text {st }}$ century $\mathrm{AD}$, during the MCA and late $19^{\text {th }}-$ mid $20^{\text {th }}$ century while colder temperatures and relatively more humid conditions were more frequent during the the Dark Ages, particularly the $7^{\text {th }}$ century $\mathrm{AD}$ and the LIA. The evolution of the lake also reflects changes in grazing and agricultural practices since the Roman Period associated to the exploitation of nearby salt mining. Periods of intense human pressure on the lake watershed occurred during the High Middle Ages (AD 890-1180) and the Modern Period (AD 1600-1830).

Keywords: Land use changes, palaeohydrology, Iberian Peninsula, Late Holocene, lake sedimentary facies 


\section{1- INTRODUCTION}

Paleolimnological studies spanning the historic period frequently have to face the problem of distinguishing climatic and anthropogenic influences - e.g. (Lotter and Birks, 1997; Tinner and $\mathrm{Hu}, 2003)$-. Climate and human impact are main factors controlling recent lake dynamics and both have played different roles since the Neolithic - e.g. (Brenner et al., 1999; Cohen, 2003) -. Multi-proxy studies represent the best strategy to assess the role of Holocene climate evolution and human activities in the lake catchments (Curtis et al., 1998; Lamb et al., 1999) although the dataset must be examined carefully while combining all the biological, geochemical and sedimentological information (Birks and Birks, 2006). The Mediterranean area is an excellent region to reconstruct evidences of past land use changes, vegetation dynamics and climate oscillations due to the presence at the same place of long high-quality historical records, archaeological sites, instrumental time series and excellent natural archives (Luterbacher et al., 2012). In the Central Pyrenees, recent studies have revealed a relation between climate and human activities during the last millennia (Riera et al., 2004; 2006; Pérez-Sanz et al., 2011; Rull et al., 2011; Corella et al., 2012), when intense land use during Roman and Medieval times coincided with more favorable (warmer) climate. The relation between favorable climate and dense human occupation, however, does not hold for the last two centuries since the latest cold phase of the LIA during the $19^{\text {th }}$ century coincided with the highest human population in the Pyrenees and the mid $20^{\text {th }}$ century land abandonment occurred during the onset of recent global warming (Corella et al., 2012). Disentangling both climate and human activities in pre-and postindustrial conditions is the way to further understand the climate vs. anthropogenic 
interactions in the environment.

Most paleolimnological and archaeological studies in NE Iberian Peninsula (IP) reveal a significant increase in the anthropogenic influences in the Iberian watersheds since the Roman times, e.g. Ebro Basin (González-Sampériz, 2004; González-Sampériz et al., 2008); Estanya Lake (Riera et al., 2004); Montcortès Lake (Corella et al., 2011a). However, it is usually difficult to ascribe specific limnological changes to human activities (Valero-Garcés et al., 2000; Kienel et al., 2005) mainly because of the lack of detailed local historical records and the complex feedbacks that existed between the anthropogenic and climate forcings. In the Mediterranean region, human activities around the lakes included not only the use of water resources for drinking or irrigation purposes, but also involved other activities, namely salt mining, fishing or hunting (Riera et al., 2004; Valero-Garcés et al., 2004). Salt has always been a strategic resource of primary importance, in particular during the pre-industrial world, due to its use in nutrition, food preservation and textile industry (Williams, 2010). Inland salt mining has traditionally produced highly disturbed landscapes as a consequence of associated parallel activities including road maintenance, supply of pastures for cattle, and deforestation (Reyes, 1998; Valero-Garcés et al., 2000).

In this paper, we present the paleoclimate and paleoenvironmental characterization of two sediment sequences from Lake Arreo, a karstic waterbody in the NW Ebro Basin, northern Spain. The deep-water core is finely laminated and the shallow-water core is dominated by carbonates and clastics. The two cores together constitute one of the few high-resolution studies in Iberia covering the last 2500 years. A palynological study on a shallow-water core was previously carried out by Peñalba (1989), although the lack of a detailed chronology prevented to ascribe the observed abrupt changes in the vegetation to the regional 
Holocene climate evolution. A previous high resolution study of short cores (Corella et al., 2011b) has demonstrated the sensitivity of the lake dynamics to climate and human activities during the last 60 years. The Arreo Lake is close $(1 \mathrm{~km})$ to the Salinas de Añana salt exploitation, the best-preserved inland salt work in NE Spain since Roman times (Plata Montero, 2008). Both shallow-water and deep-water sequences reflect the climatic evolution of the area and the impact of human activities in the lake catchment since the Roman period.

\section{2-STUDY SITE}

Lake Arreo (42 $46^{\prime} \mathrm{N}, 2^{\circ} 59^{\prime} \mathrm{W}$; $655 \mathrm{~m}$ a.s.1.) is located in the western Ebro River Basin (NE Spain). It lies on the Salinas de Añana diapir, a 5.5 x $3.2 \mathrm{~km}$ halokinetic structure involving Upper Triassic evaporite formations (Keuper facies) (Garrote Ruíz and Muñoz Jiménez, 2001) (Fig. 1). Gypsiferous materials and clays are dominant in the watershed (287 ha), although hypovolcanic rocks (ophytes) are also common (Fig. 1b). An ENE-WSW fault bounds the lake basin to the north (Martín-Rubio et al., 2005), and the cliff associated with this structure is responsible for numerous slope and masswasting deposits in the lake (Martínez-Torres et al., 1992). Lake Arreo ( $Z m a x=24 \mathrm{~m}$ deep) is the deepest water body with evaporite substrate in the IP. The lake basin originated by dissolution and collapse of evaporite rocks generating a funnel-shaped morphology (Rico et al., 1995) (Fig. 1). The lake has two contrasting environments: i) a southern shallow palustrine area that occupies $2 / 3$ of the lake total surface (6.57 ha) with a maximum depth of 3-4 m, well-mixed throughout the annual cycle, and with the highest production of biogenic carbonate associated with Chara and macrophyte incrustations (Martín-Rubio et al., 2005) and ii) a central area up to $24 \mathrm{~m}$ deep with seasonal anoxic conditions, bounded to the north by a steep scarp (González-Mozo et 
al., 2000).

The lake is currently a hydrologically open system, with an ephemeral eastern inlet and a small ephemeral western outlet flowing into the Ebro River (Figs. 1b and 1c). Saline groundwater input has an important influence on the hydrological and chemical conditions of the lake but it has not been quantified (González-Mozo et al., 2000). Chemically, the lake is subsaline $\mathrm{Ca}-(\mathrm{Mg})-(\mathrm{Na})-\mathrm{SO}_{4}-\mathrm{HCO}_{3}-(\mathrm{Cl})$. Lake Arreo limnological and hydrological features are synthetized in Table 1.

The regional climate is transitional between Atlantic and Mediterranean types. The mean annual precipitation is $670 \mathrm{~mm}$ while the mean monthly temperatures range from $20^{\circ} \mathrm{C}$ in summer to $5^{\circ} \mathrm{C}$ in winter. The site is in a transitional vegetation zone between Eurosiberian and Mediterranean bioclimatic regimes (Peinado Lorca and Rivas-Martínez, 1987). Apart from the cultivated areas, most of the lake watershed is forested (Fig. 1d). The most abundant formations are composed of subhumid mountain trees with semi-deciduous oaks (mainly Quercus faginea) and Pinus sylvestris on northfacing slope. Evergreen oaks (Quercus ilex) develop on drier south-facing exposures. The more degraded areas are covered by Juniperus communis, Aphyllantes monspeliensis, Lavandula latifolia, and Thymus vulgaris. Also present in the landscape are Fraxinus angustifolia and Ulmus minor. Cultivated areas and grazing pastures occupy the lowest parts of the valleys. The lake shorelines are colonized by hygrophytic vegetation (mainly Cladium mariscus and Phragmites australis).

\section{3- MATERIALS AND METHODS}

Two deep-water cores (ARR04-1A-1K and ARR04-1B-1K, 24 and 23.2 m water depth respectively) and one shallow-water core (ARR04-2A-1K, $10 \mathrm{~m}$ water depth) were retrieved in May 2004 with the Kullenberg coring platform from the Limnological 
Research Center (University of Minnesota, USA) (Figs. 1c and 2). Physical properties were measured at a $5 \mathrm{~mm}$ resolution with a Geotek multi-sensor core logger (MSCL). The cores were split lengthwise and imaged with a DMT core scanner. Deep-water cores were easily correlated by sedimentary facies.

The ARR04-1A-1K (6.79 m long) and ARR04-2A-1K (5.03 m long) cores were selected for this study as they represent shallow and deep-water environments. Both cores were sampled every $2 \mathrm{~cm}$ for total (TC), organic (TOC) and inorganic (TIC) carbon, total nitrogen (TN) and total sulphur (TS), and every $5 \mathrm{~cm}$ for mineralogical analyses. The TC, TS, and TOC values were analysed with a LECO 144DR elemental analyser and TN data were obtained with a VARIO MAX CN elemental analyser. Mineralogical analyses were carried out by X-ray diffraction (XRD) by an automatic Xray diffractometer SIEMENS-D500, $\mathrm{Cu}-\mathrm{K} \alpha, 40 \mathrm{kV}, \quad 30 \mathrm{~mA}$ and graphite monochromator. Elemental geochemical composition in ARR04-1A-1K and ARR042A-1K cores was obtained by X-Ray Fluorescence (XRF) using an ITRAX XRF core scanner with $20 \mathrm{~mA}$ current, $30 \mathrm{~s}$ count time and $30 \mathrm{kV}$ voltage at 5 -mm resolution. Results for each element are expressed as intensities in counts per second (cps).

Large-scale thin sections $(120 \mathrm{~mm} \times 35 \mathrm{~mm})$ were prepared after freeze-drying, followed by impregnation with epoxy resin (Araldite) under vacuum conditions (Brauer and Casanova, 2001) to carry out the description of sedimentary facies in the finely laminated intervals. Sedimentary facies were defined by visual description, microscopic smear slides and thin sections observations, combined with compositional and mineralogical analyses (Schnurrenberger et al., 2003).

A total of 102 samples for diatom analysis were obtained with sampling resolution ranging from 10 to $5 \mathrm{~cm}$, depending on the sedimentation rate. Wet sediment samples were cleaned with hydrogen peroxide and dilute $\mathrm{HCl}(10 \%)$, mounted in Naphrax, and 
analyzed with an inverted microscope. At least 400 diatom frustules were counted per sample. Taxonomic identification and assignment of planktonic and benthic habitats were based on specialized literature (Krammer and Lange-Bertalot, 1986; 1988; 1991a; 1991b; Lange-Bertalot, 2001; Krammer 2002). Pollen samples were prepared following the classical chemical method, including acetolysis (Faegri and Iversen, 1989). Pollen percentages are based on the pollen sum of AP (arboreal pollen, including trees and shrubs) and NAP (non-arboreal pollen), excluding aquatic plants and spores of Bryophyta and Pteridophyta. At least 350 terrestrial pollen grains were identified to the lowest possible taxonomic level. The differentiation of Pinus radiata pollen from Pinus sylvestris-type is based on saccus height and width, corpus length and height, and morphological characteristics (Zanni and Ravazzi, 2007). Charcoal particles coarser than $>20 \mu \mathrm{m}$ were also counted as indicators of regional fires (Tinner and $\mathrm{Hu}, 2003$ ). Non-pollen palynomorphs were identified according to Van Geel et al. (1989) and Carrión and Navarro (2002).

Sixteen AMS ${ }^{14} \mathrm{C}$ samples were analyzed on terrestrial remains, charcoal, seeds, and hydrophytes (Table 2). The final chronology is based on 12 AMS radiocarbon dates. Radiocarbon dates were calibrated with the INTCAL 09 calibration curve (Reimer et al., 2009).

\section{4- RESULTS}

\section{1- Chronology}

The chronological models of the Lake Arreo sequences were established using the mixed effect regression method (Heegaard et al., 2005) (Table 2, Figure 3). The chronological model of the deep-water core ARR04-1A-1K is constrained by 7 dates. 
For the ARR04-1A-1K model, two dates were rejected because they had too little organic matter to assure a precise date (sample CNA149, $5.7 \mathrm{~m}, 130 \pm 70{ }^{14} \mathrm{C} \mathrm{yr} \mathrm{BP}$ ) or gave incoherent, too young ages (sample POZ33482, $5.015 \mathrm{~m}, 145 \pm 30{ }^{14} \mathrm{C} \mathrm{yr} \mathrm{BP}$ ). A sedimentation rate (SR) based on the ${ }^{14} \mathrm{C}$ model $(9.5 \mathrm{~mm} / \mathrm{yr}$ for the upper part of core ARR04-1A-1K, units 1 and 2) compares well with the age model derived from ${ }^{137} \mathrm{Cs}$ dating and varve counting in a parallel UWITEC short core with a SR about $10 \mathrm{~mm} / \mathrm{yr}$ (Corella et al., 2011b) supporting the robustness of the radiocarbon chronological model. Two tie points improve the age model, the limits between former lithostratigraphic units 1 and 2 (AD 1994) and units 2 and 3 (AD 1964), which were previously dated and described through varve counting and identification of the 1963 ${ }^{137}$ Cs peak in short cores (Corella et al., 2011b).

The chronology for the shallow-water core ARR04-2A-1K is constrained by 5 radiocarbon dates obtained from plant macrorests. Two dates were rejected (CNA143 and POZ33485, 3.05 and $3.065 \mathrm{~cm}$ depth; $1140 \pm 60$ and $1380 \pm 35{ }^{14} \mathrm{C}$ yr BP respectively) because the ages show a stratigraphic reversal. The top of the shallowwater sequence is dated $\mathrm{AD} 840 \pm 60$, indicating that the palustrine realm has been affected by recent erosive processes. The SR is relatively low at the base of the shallowwater sequence $(503-350 \mathrm{~cm} ; 0.14 \mathrm{~cm} / \mathrm{yr})$, increasing up to $0.97 \mathrm{~cm} / \mathrm{yr}$ in the upper sediments $(350 \mathrm{~cm}$ - top of the core).

According to these chronologies, core ARR04-2A-1K represents shallow-water sedimentation between BC 620 and AD 860, while core ARR04-1A-1K reflects sedimentation in the deepest part of the lake since AD 585 to present times. Thus, the combined Lake Arreo sedimentary record spans the last 2570 cal. yr with an overlap of $\sim 300$ years of the two cores (Fig. 2 and 3). 


\section{2- Sedimentary facies and stratigraphy}

Core correlation for deep-water sequences was carried out based on sedimentary facies (Fig. 2). The Arreo sedimentary sequences displays 10 different facies, 5 in deep-water cores ARR04-1A-1K and ARR04-1B-1K and 5 in shallow-water core ARR04-2A-1K (Fig 4) - see full description of sedimentary facies in Tables I and II from supplementary material -. These facies make up 10 lithostratigraphic units in the sequence, units 1 to 5 in the deep-water cores and units A to D in the shallow-water core (Figs. 2 and 4). Chronological, sedimentological, and palinological features suggest that the limit between units 5 and 4 in deep-water core ARR04-1A-1K correlates with the limit between units A and B in shallow-water core ARR04-2A-1K (Fig. 2).

\subsection{1- Deep-water environment}

The sediment cores ARR04-1A-1K and 1B show an alternation of massive (facies 1 and 2), banded to finely laminated (3), and laminated (4 and 5) facies. The coarser grain size of massive facies 1 and its mineralogical composition (mafic minerals) indicate a higher energy depositional environment, short transport and a local source area (ophyte rocks). All these features point to mass wasting processes associated with the cliffs with ophyte outcrops located in the northern shore of the lake. High $\mathrm{C} / \mathrm{N}$ ratios (up to 17.4) suggest that organic matter present in facies 1 has a predominant terrestrial origin. Deposition of finer massive facies 2, mainly composed of clay minerals, indicates less energetic (or more distal) turbidite-like processes likely triggered by flooding episodes that increased sediment delivery to the lake from creeks draining the catchment. The banded to finely laminated facies 3 is composed of clayey silt and displays fining upwards textures and irregular basal surfaces. This texture is similar to small-scale turbidites and stormrelated deposits described by Noren (2002) and Corella et al (2012). The high C/N 
ratios (up to 15.1) suggest a predominant source in terrestrial plants rather than aquatic organic matter.

The deposition and preservation of finely laminated sediments such as facies 4 and 5 occurred when anoxic conditions prevailed during most of the year, with limited bioturbation (Brauer, 2004; Zolitschka, 2007). In small, relatively deep karstic lakes such as Lake Arreo these meromictic periods usually corresponded to relatively high lake levels (Martín-Puertas et al., 2009; Corella et al., 2012). However, the presence of thin laminae with endogenic prismatic gypsum crystals in facies 5 indicates that lake water chemical concentration was higher during deposition of facies 5. Facies 4 corresponds to biogenic varves with calcite and organic laminae previously described in Corella et al., (2011b).

Lithostratigraphic units in the deep-water sequence are defined by the dominance of massive and banded facies or laminated facies. Units 4 (AD 890-1180) and 2 (AD 1600-1964) are banded to laminated, black and grey units dominated by clastic facies 2 and 3 with some intervals of laminated facies 4 . Coarser clastic facies 1 are more abundant at the lower part of these three units.

Units 5 (AD 585-890), 3 (AD 1180-1600) and 1 (AD 1964-Present-day) are variegated, finely laminated units rich in calcite (facies 4) and gypsum laminae (facies 5) with minor clastic facies, except in units 3 and 1, with abundant layers of coarse facies 1. These units have higher TIC, calcite and gypsum contents and less clay minerals. The preservation of fine laminations with gypsum suggests meromictic conditions and higher chemical concentration of the waters during deposition of these units.

\subsection{2- Shallow-water environment.}

Shallow-water facies in core ARR04-2A-1K include massive (facies 6, 7, and 8) and 
banded to laminated carbonate-rich facies (9 and 10). Composition and textures of facies 8 indicate strong alluvial influence in the shallow-water, particularly during deposition of conglomerate subfacies 8.2. The deposition of organic (up to $13.3 \%$ of TOC) massive to weakly laminated facies 7 and the progressive increase in the $\mathrm{C} / \mathrm{N}$ ratio (up to 17) suggest wetland conditions with high terrestrial organic matter production and accumulation. The massive, carbonate- rich facies 6 is interpreted as shallow-water deposition with reworking during periods of higher run-off in the watershed.

The banded carbonated facies 9 and 10 reflect deposition in a carbonateproducing shallow-water environment. The finer facies 9 suggests relatively deeper depositional environment, while the abundance of Chara and gastropod fragments in facies 10 indicates shallower littoral environments.

Four units have been defined in the shallow-water sequence (Fig. 4): Unit D (BC 620- AD 150) is composed of a fining upward sequence of conglomerates and sandy silts (subfacies 8.2 and 8.1) reflecting the transition from an alluvial-influence lacustrine littoral to a wetland-lacustrine littoral. During unit C (AD 150-465) carbonate deposition dominated the shallow-water environments (facies 7). The transition from this carbonate-producing sub-environment to an organic-accumulating wetland/shallow lake is illustrated by the carbonate decrease and organic carbon increase trend (Fig. 4). Unit B (AD 465-830) is composed of banded carbonate facies 9 and 10. More coarser facies 10 and a $22 \mathrm{~cm}$-thick interval of organic facies 7 occur in the lower part of this unit (subunit B.IV) while carbonated facies 9 dominates in subunit B.II. Unit A (AD 830-860) is composed of carbonate clastic, massive facies 6 and 9.

\section{3- Geochemistry}


The XRF geochemical record obtained in both shallow and deep-water cores shows a clear correspondence with the sedimentary facies (Fig. 4). We have selected two element ratios to illustrate the geochemical variability of the Arreo record. Sr/Ca ratio is widely used as a paleosalinity indicator due to a higher $\mathrm{Sr}$ uptake of carbonates under more saline conditions -e.g. (Dodd and Crisp, 1982). A previous study in several Iberian lakes, including Lake Arreo, has also shown a direct relation between $\mathrm{Sr} / \mathrm{Ca}$ ratio in lacustrine carbonates and $\mathrm{Sr} / \mathrm{Ca}$ ratio in lake waters (Anadón et al., 2002). Therefore $\mathrm{Sr} / \mathrm{Ca}$ ratio in the sediment has been selected as a reliable proxy of water salinity in Lake Arreo showing higher values in units 4 and 2.b. We use the $\mathrm{Ca} / \mathrm{Ti}$ ratio to identify intervals with elevated endogenic calcite precipitation and low clastic input (units 5, 3 and 1).

\section{4- Pollen Stratigraphy}

The pollen taxa are grouped following Behre (1981), Gaillard (2007), Carrión et al. (2010), and the modern flora and plant ecology for the area. The pollen stratigraphy in the two cores comprises six local pollen zones (LPAZ): Zones LPAZ 1 to 3 in the shallow-water core ARR04-2A-1K, and zones LPAZ 3 to 6 in deep-water core ARR041A-1K (Fig. 5) - see Table III of the supplementary material for a more exhaustive description of local pollen zones -.

LPAZ 1 (core ARR04-2A-1K, 429-302 cm, AD 0- 505) is characterized by strong fluctuations in the arboreal content (AP 40-80\%; mainly deciduous and evergreen Quercus, Fagus, Corylus, and Pinus diploxylon-type at the base of the zone), as well as the highest charcoal values (up to 65\%). Meadows and pasture indicators (30\%) and Cyperaceae (20\%) dominate the non-arboreal pollen types (NAP). LPAZ 2 (core ARR04-2A-1K: 302-48 cm, AD 505-790) is characterized by maxima of Fagus and 
deciduous oaks of $30 \%$ and $25 \%$ respectively. Human impact indicators such as charcoal, cultivated plants, ruderals, meadows and pastures and Sporormiella taxa decrease while hydrophytes increase.

LPAZ 3 (core ARR04-2A-1K: 48-0 cm; core ARR04-1A-1K: 679-545 cm; AD 790-1180) is characterized by significantly lower values of the arboreal taxa (AP < 40\%). Both oak types and beech decrease. All taxa related to anthropogenic activities reach maxima - cultivated plants $(8 \%)$, ruderals $(10 \%)$, meadow and pasture indicators (30\%), Glomus (5\%), Sporormiella (8\%). and charcoal values (30\%) -. Pediastrum and Botryococcus have sequential maxima up to $20 \%$.

In LPAZ 4 (core ARR04-1A-1K: 545-414 cm, AD 1180-1600), deciduous oak and beech dominate and Poaceae is the main herbaceous taxon (25-35\%). Percentages of ruderals, cultivated plants, and indicators for pasture and grazing (Sporormiella) decrease.

In LPAZ 5 (core ARR04-1A-1K: 414-130 cm, AD 1600-1800) AP values are high (45-70\%) with an increase in evergreen Quercus, Juniperus and Pinus sp. while significant fluctuations in deciduous oak and a sharp decrease in Fagus occur. Charcoal values strongly fluctuate with peaks at $397 \mathrm{~cm}(45 \%), 305 \mathrm{~cm}(20 \%)$, and $245 \mathrm{~cm}$ (25\%). Sporormiella increases at the end of this zone. Pinus sp. Pinus radiata, evergreen oaks and Juniperus dominate LPAZ 6 (core ARR04-1A-1K: 130-0 cm, AD 1800-Present) and a slight decrease in hydrophytes occurs in this zone.

\section{5- Diatoms}

Diatom assemblages are composed of a total of 110 taxa distributed among 28 genera, being Navicula (15), Nitzschia (11), Gomphonema (7) and Cymbella (7) the genera with 
more species. Most taxa found are typical of benthic habitats (i.e. epipelon, periphyton or epiphyton) or are tychoplanktonic. Strictly planktonic taxa are represented by only three species of the genus Cyclotella (C. distingüenda, C. pseudostelligera and $C$. radiosa). Only $22 \%$ of taxa have a relative abundance greater than $5 \%$ in at least one of the samples, whereas $29 \%$ have abundances of $1-5 \%$, and the rest $<1 \%$. Four diatom zones were identified (Fig. 6) - see table IV of the supplementary material for further description of the diatom zones-:

The lower part of the sequence (core ARR04-2A-1K: 500 - $412 \mathrm{~cm}, \mathrm{BC} 620-\mathrm{AD}$ 160, unit D) is sterile. DZ4 (Core ARR04-2A-1K: 412-349 cm, AD 160-465) is dominated by periphytic taxa of the genus Fragilaria (F. brevistriata and F. pinnata) reaching their maximum abundance in DZ 4b (412-383 cm, AD 160-300). Achnanthes minutissima also occur in smaller percentages. A significant increase in planktonic (Cyclotella distingüenda up to 33\%) and dystrophic (Gomphonema angustum up to 39 \%) species occur in DZ4a (383-349 cm, AD 300-465)

DZ 3 (Core ARR04-2A-1K, 349-30 cm, core ARR04-1A-1K 679-613 cm; AD 465-820) shows an increase in the P:B index. Epiphytic Epithemia adnata and Cymbella helvetica (0-30\%) dominate the lower interval DZ 3b (349-180 cm, AD 465-610) and planktonic Cyclotella distingüenda is the species in the lower part of DZ 3a (core ARR04-2A-1K: 180-30 cm, and core ARR04-1A-1K: 679-613 cm; AD 610-820).

DZ 2 (AD 820-1180) is characterized by low values of Cyclotella distingüenda and an increase in the genus Fragilaria. The shallow-water environment (core ARR042A-1K: $30-0 \mathrm{~cm})$ is dominated by periphytic Fragilaria brevistriata $(3-75 \%)$ and a decrease of Gomphonema angustum. The deep-water environment (core ARR04-1A1K: 613-545 cm) shows the highest percentages of littoral taxa Cocconeis placentula, and Achnanthes minutissima (low P:B ratio). The planktonic species Cyclotella 
distingüenda dominates DZ 1 (core ARR04-1A-1K, 545-0 cm, AD 1180- Present) with the highest percentages up to $96 \%$ of the total at DZ $1 \mathrm{~b}(414-130 \mathrm{~cm}, \mathrm{AD} 1600-1800)$. Benthic species decrease progressively although Achnanthes minutissima slightly increase towards the top of the sequence DZ 1a $(130-0 \mathrm{~cm}$ : 1800-Present). P:B ratio increase in DZ-1c, displaying the highest values in DZ-1b, and progressively decrease at the top of the sequence (DZ-1A).

\section{5- DISCUSSION}

The Lake Arreo sedimentary sequence illustrates the climate and environmental variability over the last $2.5 \mathrm{kyr}$ in a transitional Atlantic-Mediterranean lowland area. It also provides an opportunity to evaluate the impact of human activities in the landscape since the Late Iron Age $\left(5^{\text {th }}-3^{\text {rd }}\right.$ centuries $)$ because of the intense anthropogenic pressure and the exploitation in the Salinas de Añana salt work (Figs. 7 and 8).

\section{1- Depositional evolution of Lake Arreo during the last 2,500 years}

Five main depositional stages are distinguished for Lake Arreo for the last 2,570 cal. yr $\mathrm{BP}$, based on the evolution of the sedimentary facies, diatoms and some palynological data (aquatics and hydrophytes) (Figs 7 and 8):

\section{$\underline{\text { 5.1.1- Stage I (Unit D): Alluvial - influenced wetland (BC 630- AD 150) }}$}

Deposition of conglomerate facies (unit D) and non-preservation of pollen and diatoms reflect dominant alluvial processes in the southern margin of the lake during BC 630415. During this period, the lake was restricted to the deep hole, and the littoral areas were dominated by palustrine - alluvial deposition. At around $400 \mathrm{BC}$, a progressive 
transition towards a shallow wetland environment started, marked by increasing accumulation of organic matter up to $150 \mathrm{AD}$ (unit D).

\subsection{2- Stage II (Unit C): Wetland - lacustrine environment (AD 150-465)}

After a period of a shallow carbonate-producing lake between AD 150 and 300 (unit C, facies 7.1), wetland conditions characterized by high terrestrial organic matter production and accumulation (unit $\mathrm{C}$, subfacies 7.2) dominated the shallow-water environment. The low $\mathrm{P}: \mathrm{B}$ index, the dominance of periphytic diatom species Fragilaria brevistriata and Fragilaria pinnata, and, to a lesser extent, the benthic Achnanthes minutissima (DZ-4b, Fig. 6) corroborate the establishment of a shallow, turbid wetland/shallow-lake ecosystem. The maximum percentages of Cyperaceae pollen for the whole sequence occurred during this interval indicating that a sedge fen at the littoral margin of the lake was well developed. The dominance of fine-grained facies with higher clay content could also be influenced by the presence of this wide palustrine vegetation belt acting as a buffer for coarser material from the watershed.

5.1.3- Stage III (Units B and 5): Deep, meromictic oligotrophic lake with well$\underline{\text { developed shallow carbonate platform (AD 465-790) }}$

During this stage laminated facies were deposited in the deep areas of the lake and carbonate-rich sediments accumulated in the shallows. A shallow carbonate-producing platform was well developed in the southern littoral margin of the lake (unit B, core ARR04-2A-1K) and meromictic sub-environments occurred in the central, deepest areas, with formation of biogenic varves (unit 5, core ARR04-1A-1K). The increase in the diatom Gomphonema angustumi, a species characteristic of low-trophic-state 
waters, in both sub-environments suggests reduced nutrient input and oligotrophic lake waters during this period.

In the littoral area, the increase of benthic diatoms and the absence of hydrophytes, along with the presence of organic-rich facies (unit B.IV), suggest low lake levels until AD 500. Later, the increase in hydrophytes and P:B ratio marks a progressive increase in the lake level up to AD 580. The abundance of Chara sp. suggests water depths oscillating between 0.5 and $3 \mathrm{~m}$ in these littoral areas (Hannon and Gaillard, 1997). Lake level continued to increase as banded carbonate facies without gastropods and less Chara remains (facies 9) were deposited until AD 790 (unit B.II).

\subsection{4- Stage IV (Unit 5, 4 and 3): Fluctuating, saline to brackish lake (AD 790-1600)}

The development of a saline lake started at AD 790 when gypsum precipitation increased. Lower lake level occurred as reflected by the low P.B ratio (Fig 8). The welldeveloped carbonate platform could have become an erosional site providing sediment to the deep-water areas. At around AD 890, laminated facies deposition was replaced by fine, clay-rich facies 2 (Unit 4). An increase in the clastic input also occurred in the shallow-water core ARR04-2A-1K at the top of Unit A (facies 6 with less carbonate and higher clastic and organic content) suggestive of a return to wetland or littoral type deposition. The lower percentages of Cyclotella distingüenda (Fig. 6) indicate more frequent mixing conditions and shorter periods of anoxia in the deeper areas of the lake. The sharp increase of Botryococcus in unit 5 may be related to increased salinity and dystrophic conditions in the lake (Davis et al., 1977; Medeanic et al., 2003). The high Sr/Ca values between AD 900-970 and AD 1040-1300 mark the period of highest 
salinity in Lake Arreo. The increase in Pediastrum and Fragilaria brevistriata in both shallow and deep-water environments (Figs. 5 and 6) may indicate a change to mesotrophic conditions at around $\mathrm{AD} 800$, and the subsequent increase in Achnantes munitissima and Cocconeis placentula, and disappearance of Gomphonema angustum reveal a higher trophic state of the lake until AD 1300 (Fig. 6). The high sediment delivery to the lake ended in AD 1180 (Fig. 8).

Fluctuating but generally higher lake levels and meromictic conditions prevailed in Lake Arreo since $\mathrm{AD} 1300$, characterized by low $\mathrm{Sr} / \mathrm{Ca}$ values, increasing hydrophytes percentages at LPAZ 4 and a progressive increase in the P:B ratio (Fig. 8). Lake waters recovered mesotrophic to oligothrophic levels, as indicated by an increase of Gomphonema angustum and the decrease in Cocconeis placentula (DZ-1c, Fig 6). During the period AD 1450 - 1600, coarse clastic sediments reached the distal areas of the lake (facies 1).

5.1.5- Stage V (Units 2 and 1): Meromictic lake with high clastic input (AD 1600$\underline{\text { Present-day) }}$

This stage is defined by the dominance of biogenic varves and fine clastic facies 2 . Increased sediment delivery with coarser deposition occurred between AD 1600-1730 (unit 2.c) followed by an increase in deposition of clay-rich facies 2 (unit 2.b) and the dominance of biogenic varves since AD 1790 (unit 2.a). The relatively high $\mathrm{Sr} / \mathrm{Ca}$ ratio in the sediment during the periods AD 1600-1640 and AD 1730-1790 suggest a relatively higher salinity, although without reaching gypsum saturation as during the previous stage. The dominance of biogenic varves suggests relatively high lake levels and more frequent anoxic conditions for the last two centuries. The last 30 years are characterized by a significant increase in the sediment delivery to the lake with 
abundant clastic facies 1 and 3 (AD 1964-Present day, unit 1).

\section{2- Climate variability and human impact in NE Spain during the Late Holocene}

\subsection{1- The Iberian - Roman Era (BC $6^{\text {th }}-\mathrm{AD} 5^{\text {th }}$ centuries)}

The presence of coarse alluvial facies at the base of the Arreo Lake sequence points to more arid condition prior to the $6^{\text {th }}$ century BC. Although clastic facies dominated in Arreo until $150 \mathrm{AD}$, the fining upward textures and the increase in organic matter indicate progressive higher water availability during this period. The establishment of a well-developed carbonate platform at 150 AD marks a significant increase in humidity. Lake level continued high until the end of the Roman period in the $5^{\text {th }}$ century, with a small decline between AD 300 and AD 465.

The Lake Arreo sequence supports the regional significance of the pre-Roman arid period in the Iberian Peninsula and the regional extent of the large hydrological change occurred in the Peninsula during Iberian-Roman times $\left(3^{\text {rd }}\right.$ century BC- $5^{\text {th }}$ century AD), although the timing shows some discrepancies. In the central Ebro Basin, relatively more humid conditions started around 2 kyr ago (González-Sampériz et al., 2008) whereas in the central Pre- Pyrenees higher lake levels started around the $1-3^{\text {rd }}$ centuries AD - Lake Estanya (Morellón et al., 2008), Lake Montcortès (Corella et al., 2011a) -. The increase in humidity during the Iberian - Roman times seemed more intense in southern Spain as recorded in Lake Zoñar (Martín-Puertas et al., 2009) with an earlier onset at $5^{\text {th }}$ century $\mathrm{BC}$, an arid pulse around 1 st century $\mathrm{AD}$, and a final humid pulse occurred between $\mathrm{AD} 150$ and $\mathrm{AD}$ 450. Fluvial records also show increased river activity in NE Spain between BC 50- AD 120 (Benito et al., 2008).

The presence of several Roman archaeological sites in the vicinity of the Añana diapir suggests an early salt exploitation. One of these sites, known as Las Ermitas is 
located $5 \mathrm{~km}$ away, near a branch of the Via Iter XXXIV that connected Astorga (NW Spain) and Burdeaux (SW France). Archaeological research documented an important human occupation of the region between the $1^{\text {st }}$ and $5^{\text {th }}$ century AD (Filloy Nieva and Gil Zubillaga, 2000). In our lake sequence, several indicators suggest human occupation in the lake Arreo surroundings during the Roman Era. The high percentages of charcoal and low percentages of deciduous and evergreen oaks in the pollen spectra between AD 0-150 (top of unit D, Figs 5 and 8) indicate a high frequency of fires most likely caused by anthropogenic activities. Pinus dominates the pollen diagram probably because of over-representation and preservation processes frequently associated with fire events. The anthropogenic origin of such fires is consistent with what is known about traditional forest management during the Roman Period, as widely documented in Europe - e.g. (Küster, 1994) -.

Presence of F. brevistriata and F. pinnata (DZ-4, Fig. 6) in diatom assemblages, taxa which can tolerate disturbance and higher nutrient levels (Van Dam et al., 1994), also suggests an increase in human activities in the watershed as these taxa are directly related to the clastic input to the lake (Corella et al., 2011b). The existence of a large fen around the Lake Arreo palustrine area (unit C and LPAZ 1) would have favored the expansion of pastures between the $2^{\text {nd }}$ and the $5^{\text {th }}$ centuries $\mathrm{AD}$ as it is well-known that Roman used fens as wet pastures in the subalpine woodland (Ejarque et al., 2010). Contrary to the decrease in grazing activities documented in the Western Pyrenees between AD 250-550 (Mazier et al., 2009), anthropogenic activities in the lowlands around Lake Arreo continued during this period, suggesting the importance of the local economy based on the need of livestock to transport salt in the Salinas de Añana (Plata Montero, 2008). 
$\underline{\mathrm{AD})}$

Relatively high lake levels dominated in Lake Arreo between AD 580 and 790. Although charcoal peaks are smaller than during Roman times, the increase in the helyophytic pioneers Ericaceae and Corylus after charcoal peaks, along with the expansion of ruderals and cultivated plants next to a first peak of Sporormiella around $5^{\text {th }}$ century $A D$, indicate intensive land use during the onset of the Visigoth period (450 600 AD). Moister conditions are also reflected in a small forest recovery dominated by deciduous oaks and a Fagus expansion (Figs. 6 and 8).

The decrease in pastures and Sporormiella during the Early Middle Ages (5-9 centuries) indicates lower grazing activities in the watershed. The reduction of livestock was most probably linked to the decrease in the salt production and transport during the Visigoth period (5- $6^{\text {th }}$ centuries AD) (Plata Montero, 2008). The combination of reduced human activities in the lake watershed and the forest recovery that took place during this period lead to a decrease in sediment delivery to the lake (units 5 and B), as well as to oligotrophic waters (DZ-3a). The small decrease in AP values and the charcoal peak recorded at around AD 800 (Figs. 5 and 8) may be related to the documented fires in the area during the Arab incursions between AD 770 and AD 885 (Martínez-Díez, 2005). Forest burning was a common strategy used during the Christian and Muslim wars and is also documented in other Pre-Pyrenean lake records, e.g. from Lakes Estanya (Riera et al., 2004) and Lake Montcortès (Rull et al., 2011) -

The increase in cultivated lands, pastures, ruderals and Sporormiella and an increase of sediment input to the lake, mark more intense human pressure in the lake catchment since AD 830 (unit A) that can be related to the first Medieval settlements in 
the area between the 8 and $10^{\text {th }}$ centuries (i.e. Arreo and Los Lagos) (Pastor Díaz de Garayo, 2004).

\subsection{3- The Medieval Climate Anomaly and the High and Late Middle Ages $\left(9-13^{\text {th }}\right.$} centuries):

The most intense arid phase reflected by increased salinity and lower lake levels occurred between AD 890 and 1300 characterized by the Sr/Ca ratio increase and low P:B index (Fig. 8). The decreasing trend in deciduous Quercus and Fagus (Figs. 5 and 8) since the $8^{\text {th }}$ century can be interpreted as a progressive increase in arid conditions, although the intense human activities during this period should also have had a strong impact on the forest.

This arid period occurring during the MCA time (AD 900 -1300) has also been described in previous paleoclimatic reconstructions in NE Spain and the western Mediterranean area (Magny, 2004; Martín-Puertas et al., 2010; Morellón et al., 2012; Moreno et al., 2012). A unique phase of lower salinity occurred between AD 970 and 1040 (blue band in Fig. 8). This short humid phase is synchronous to an increase of precipitation events per year in Lake Montcortès (Corella et al., 2012) and increased frequency in large magnitude floods in the IP between AD 950 -1150 (Thorndycraft and Benito, 2006).

The High Middle Ages (10-12 ${ }^{\text {th }}$ centuries) witnessed the most intense land use of the last two millennia, with the highest clastic input to the lake between AD 890 and 1180. Deforestation and farming activities could have triggered a dramatic increase in run-off and deposition of clastic material in the distal areas of the lake (Unit 4, fig 8). The increase in ruderals, cultivated taxa and Sporormiella, the presence of Glomus and the large peaks of charcoal also indicate intense land use during the High Middle Ages. 
The occurrence of fire events and deforestation practices can be linked to expansion of crops and pasture areas and to the use of wood for fuel and construction material (Aizpuru et al., 1990).

Changes in the lake during the late $12^{\text {th }}$ century (run-off reduction, mesotrophic lake conditions) are consistent with the abandonment of the medieval settlements in the lake watershed during the first half of the $12^{\text {th }}$ century when a massive emigration to the village of Salinas de Añana occurred, and numerous fields located in the catchment were abandoned (Plata Montero, 2008) (Fig. 7)

5.2.4- The Little Ice Age, from the Middle Ages to the Modern Period (14-18 centuries):

Decreasing lake salinity and forest recovery after AD 1300 (Fig. 8) indicate a progressive increase in effective moisture in the area that lasted until AD 1870. Particularly during the period AD 1640-1730 and AD 1790-1870 with no deposition of gypsum laminae, an increase in the P:B index values and low $\mathrm{Sr} / \mathrm{Ca}$ ratios (Fig. 8), moister conditions would have prevailed. The oscillating but relatively humid nature of this period in Arreo synchronous with the LIA (AD 1300 -1870) is consistent with the dendroclimatic and lacustrine paleohydrological reconstructions in the Pyrenees (Morellón et al., 2012), the Alps (Magny et al., 2008) and southern Spain (Martín Puertas et al., 2009), and with the higher flood frequency that occurred in Spain between AD 1430-1685 (Thorndycraft and Benito, 2006). The Lake Arreo record also supports a complex paleohydrological structure for the LIA as evidenced in other areas in the IP (Morellón et al., 2012) and the Alps (Magny et al., 2008). In particular, the arid pulse in Lake Arreo at AD 1730-1790 occurs synchronically in several sites of the NE Spain (Barriendos and Llasat, 2003; Morellón et al., 2011; Corella et al., 2012) 
The expansion of AP clearly indicates a decrease of human activity in the watershed during the Late Middle Ages $\left(13^{\text {th }}-15^{\text {th }}\right.$ centuries) (Figs. 7 and 8$)$. This could be a reflection of non-favorable climatic conditions during the first part of the LIA or the so-called "low medieval crisis" responsible for a decline in population in this area (Díaz de Durana, 1986). Since AD 1600 an increase in the sediment delivery to the lake occurred (unit 3.c, Fig. 8), synchronous to the onset of the Modern period characterized by renewed agricultural activities in the area. Forest dominated during the Modern Period $\left(15^{\text {th }}-18^{\text {th }}\right.$ centuries) (Fig. 7), although the expansion of evergreen Quercus, Pinus and Juniperus during the LIA (see pollen diagram) is not consistent with colder and more humid conditions. Thus, anthropogenic factors also seem to have influenced local forests during this period. A plausible hypothesis would link deforestation of oak forest and beech to a source for material construction for the salt work, enabling the dispersal of Pinus pollen. Another possible explanation is related to the colonizing and heliophilic nature of some of these taxa, such as Juniperus and Quercus ilex after the anthropogenic fires that occurred during the modern period. The abrupt increase in Sporormiella was linked to grazing activities during the second half of the $18^{\text {th }}$ and the first decades of the $19^{\text {th }}$ century (Fig. 5). The increase in cattle raising is consistent with the period of maximum salt production in the Salinas de Añana salt work throughout its history (Plata Montero, 2008), when abundant livestock for salt transport was needed. During the Modern period, the salt mines experienced a progressive increase from 2500 salt evaporation pans in 1401 to 3367 at the beginning of the $19^{\text {th }}$ century (Plata Montero, 2008) because the Spanish Crown monopolized and centralized production, enhancing productivity and sales. The decrease in grazing and pastoral activities documented in the nearby Iraty Mountains between AD 1750 and 1825 (Mazier et al., 2009) highlights again the local nature of this increase in pasture areas in Lake Arreo 
watershed, dependent on the salt production dynamics.

\subsubsection{From the end of the Little Ice Age to the present (19-20 $0^{\text {th }}$ centuries).}

A decrease in Fagus and deciduous Quercus since AD 1870 (Figs. 5 and 8) suggest more arid conditions in the area after the end of the LIA and during the warmer $20^{\text {th }}$ century. Nevertheless, the presence of calcite biogenic varves (units 2.a and 1) indicates that meromictic conditions prevailed until the second half of the $20^{\text {th }}$ century (Corella et al., 2011b).

During the last century arboreal pollen remained high, likely as a result of the use of concrete instead of timber for the salt work structures during the $20^{\text {th }}$ century (Plata Montero, 2008). In addition, the occurrence of Pinus radiata pollen at AD 1870 marks the onset of the reforestation in the Basque country with this American pine (Espinel et al., 1995). Since the 1960s, the loss of economic competitiveness against coastal salt mines resulted in an abrupt reduction from 5648 salt evaporation pans in 1960 to 40 pans in 2000. As occurred in most mountain areas in the Pyrenees, the economic changes during the mid 1950s forced people to migrate to the cities and the area was depopulated (Plata Montero, 2008). The high sediment delivery to the lake during the last 30 years reflects the increase in cultivated areas due to mechanization and different small-holding activities (Corella et al., 2011b).

\section{6- CONCLUSIONS}

The multiproxy study carried out for the Lake Arreo sediment sequence provides a paleohydrological and paleoenvironmental reconstruction of the area since BC 600 and a remarkable example of the interactions between the impact of human activities in the 
catchment and local and regional climate fluctuations. The Lake Arreo record shows an arid period prior to $6^{\text {th }}$ century $\mathrm{BC}$, a large increase in water availability during the Roman Humid Period, particularly during the $1^{\text {st }}-4^{\text {th }}$ centuries AD, higher lake levels and less saline conditions during the Dark Ages Cold Period (AD 580-790) and the Little Ice Age (AD 1300-1870). Lower lake levels, a response to increasing regional aridity, were recorded during the Medieval Climate Anomaly (AD 890-1300) and the $20^{\text {th }}$ century. Comparison of the main hydrological phases in Lake Arreo with other Iberian records demonstrates the coherence of the main climatic phases in the Iberian Peninsula during the last 2500 years, at the same time highlighting the spatial and temporal variability and some latitudinal differences.

Human activities have also played a dynamic role in the transformation of the regional environment as the landscape provided natural resources (wood, land for crops and pastures) for the exploitation of the Salinas de Añana inland salt work, closed to Lake Arreo, since the Roman Period. Periods of intense human pressure on the lake watershed occurred during the High Middle Ages (AD 890-1180) and the Modern Period (AD 1605-1830)

\section{7- ACKNOWLEDGMENTS}

Financial support for this research was provided by the Spanish Inter-Ministry of Science and Technology (CICYT), through the projects LIMNOCLIBER (REN200309130-C02-02), IBERLIMNO (CGL2005-20236-E/CLI), LIMNOCAL (CGL200613327-C04-01), GLOBALKARST (CGL2009-08415) and GRACCIE (CSD2007-00067). Additional funding was provided by the Aragonese Regional Government-Caja 
Inmaculada, with a travel grant to GFZ (Potsdam). Provincial Council of Alava and the Basque Water Agency provided institutional permits for fieldwork. We acknowledge Sebastián Perez, Penélope González-Sampériz and prof. Herb Wright for their valuable comments on the manuscript.

\section{6- REFERENCES}

Aizpuru, I., Catalán, P., Garin, F., 1990. Guía de los árboles y arbustos de Euskal Herria. Vitoria-Gasteiz, Gobierno Vasco.

Anadón, P., Utrilla, R., Vázquez, A., 2002. Mineralogy and Sr-Mg geochemistry of charophyte carbonates: a new tool for paleolimnological research. Earth and Planetary Science Letters 197, 205-214.

Barriendos, M., Llasat, M.C., 2003. The Case of the 'Maldá' Anomaly in the Western Mediterranean Basin (AD 1760-1800): an example of a strong climatic variability. Climatic Change 61, 191-216.

Behre, K.E., 1981. The interpretation of anthropogenic indicators in pollen diagrams. Pollen et Spores 13, 225-245.

Benito, G., Thorndycraft, V.R., Rico, M., Sánchez-Moya, Y., Sopeña, A., 2008. Palaeoflood and floodplain records from Spain: Evidence for long-term climate variability and environmental changes. Geomorphology 101, 68-77.

Brauer, A., 2004. Annually laminated lake sediments and their palaeoclimatic relevance. Springer.In: Fischer H, Kumke T, Lohmann G, Flo“ser G, Miller G, von Storch H, Negendank JFW (Eds), The climate in historical times. Towards a synthesis of Holocene 
proxy data and climate models. Springer, Berlin, pp 109-128.

Brauer, A., Casanova, J., 2001. Chronology and depositional processes of the laminated sediment record from Lac d'Annecy, French Alps. Journal of Paleolimnol 25, 163-177.

Brenner, M., Whitmore, T.J., Curtis, J.H., Hodell, D.A., Schelske, C.L., 1999. Stable isotope $(\delta 13 \mathrm{C}$ and $\delta 15 \mathrm{~N})$ signatures of sedimented organic matter as indicators of historic lake trophic state. J Paleolimnol 22, 205-221.

Birks, H.H. and Birks, H.J.B., 2006. Multi-proxy studies in palaeolimnology. Veget Hist Archaeobot 15: 235-251.

Carrión, J.S., Fernández, S., Jiménez-Moreno, G., Fauquette, S., Gil-Romera, G., González-Sampériz, P., Finlayson, C., 2010. The historical origins of aridity and vegetation degradation in southeastern Spain. J Arid Environ 74, 731-736.

Carrión, J.S., Navarro, C., 2002. Cryptogam spores and other non-pollen microfossils as sources of palaeoecological information: case-studies from Spain. Ann. Bot. Fenn 39, 114.

Cohen, A.S., 2003. Paleolimnology. The history and evolution of lake systems. Oxford University Press, New York.

Corella, J., Moreno, A., Morellón, M., Rull, V., Giralt, S., Rico, M., Pérez-Sanz, A., Valero-Garcés, B., 2011a. Climate and human impact on a meromictic lake during the last 6,000 years (Montcortès Lake, Central Pyrenees, Spain). J Paleolimnol 46, 351-367.

Corella, J.P., Amrani, A., Sigró, J., Morellón, M., Rico, E., Valero-Garcés, B., 2011b. Recent evolution of Lake Arreo, northern Spain: influences of land use change and 
climate. J Paleolimnol 46, 469-485.

Corella, J.P., Brauer, A., Mangili, C., Rull, V., Vegas-Vilarrúbia, T., Morellón, M., Valero-Garcés, B.L., 2012. The 1.5-ka varved record of Lake Montcortès (southern Pyrenees, NE Spain). Quaternary Res 78, 323-332.

Curtis, J.H., Brenner, M., Hodell, D.A., Balser, R.A., Islebe G.A. and Hooghiemstra, H., 1998. A multiproxy study of Holocene environmental change in the Maya Lowlands of Peten, Guatemala. J Paleolimnol 19, 139-159.

Davis, O.K., Kolva, D.A., Mehringer Jr., P.J., 1977. Pollen analysis of Wildcat Lake, Whitman County, Washington: The last 1000 years. Northwest Sci 51, 13-30.

Díaz de Durana, J.R., 1986. Álava en la Baja Edad Media. Crisis, recuperación y transformaciones socioeconómicas (1250-1525). Diputación Foral de Álava, Vitoria.

Dodd, J.R., Crisp, E.L., 1982. Non-linear variation with salinity of $\mathrm{Sr} / \mathrm{Ca}$ and $\mathrm{Mg} / \mathrm{Ca}$ ratios in water and aragonitic bivalve shells and implications for paleosalinity studies. Palaeogeography, Palaeoclimatology, Palaeoecology 38, 45-56.EEA, 2000. NATLAN. Nature/land cover information package. European Environmental Agency, Luxembourg. Ejarque, A., Miras, Y., Riera, S., Palet, J.M., Orengo, H.A., 2010. Testing microregional variability in the Holocene shaping of high mountain cultural landscapes: a palaeoenvironmental case-study in the eastern Pyrenees. J Archaeol Sci 37, 1468-1479.

Espinel, S., Aragonés, A., Ritter, E., 1995. Performance of different provenances and of the local population of the Monterey pine (Pinus radiata D Don) in northern Spain. Ann. For. Sci. 52, 515-519.

Faegri, K., Iversen, J., 1989. Textbook of Pollen Analysis, Fourth ed., New York. 
Filloy Nieva, I., Gil Zubillaga, E., 2000. La romanización en Álava, Catálogo de la exposición permanente del Museo de Arqueología de Álava, Vitoria-Gasteiz.

Gaillard, M.J., 2007. Pollen methods and studies_archaeological applications, in: Elías, S.A., (Ed.), Encyclopedia of quaternary science. Elsevier, Amsterdam, pp. 25752595.

Garrote Ruíz, A., Muñoz Jiménez, L., 2001. Mapa Geológico del País Vasco Escala 1:25.000, in: EVE (Ed.), Mapa Geológico del País Vasco y memoria. Departamento de Industria, Agricultura y Pesca del Gobierno Vasco, Bilbao.

González-Mozo, M.E., Chicote, A., Rico, E., Montes, C., 2000. Limnological characterization of an evporite karstic lake in Spain (lake Arreo). Limnética 18, 91-98.

González-Sampériz, P., 2004. Evolución paleoambiental del sector central de la Cuenca del Ebro durante el Pleistoceno Superior y Holoceno. Instituto Pirenaico de Ecología CSIC / Dpto. de Ciencias de la Antigüedad - Universidad de Zaragoza, Zaragoza.

González-Sampériz, P., Valero-Garcés, B.L., Moreno, A., Morellon, M., Navas, A., Machin, J., Delgado-Huertas, A., 2008. Vegetation changes and hydrological fluctuations in the Central Ebro Basin (NE Spain) since the Late Glacial period: saline lake records. Palaeogeogr Palaeocl 259, 136-115.

Hannon, G.E., Gaillard, M.-J., 1997. The plant-macrofossil record of past lake-level changes. J Paleolimnol 18, 15-28.

Heegaard, E., Birks, H.J.B., Telford, R.J., 2005. Relationships between calibrated ages and depth in stratigraphical sequences: an estimation procedure by mixed-effect 
regression. The Holocene 15, 612-618.

Kienel, U., Schwab, M.J., Schettler, G., 2005. Distinguishing climatic from direct anthropogenic influences during the past 400 years in varved sediments from Lake Holzmaar (Eifel, Germany). J Paleolimnol 33, 327-347.

Krammer, K., 2002. Diatoms of Europe. Diatoms of the European Inland Waters and Comparable Habitats, in: A.R.G. Gantner Verlag K.G, R. (Ed.), p. 584.

Krammer, K., Lange-Bertalot, H., 1986. Süsswasserßora von Mitteleuropa. Bacillariophyceae. 1. Teil: Naviculaceae., in: Verlag., G.F. (Ed.), Stuttgart, p. 876.

Krammer, K., Lange-Bertalot, H., 1988. Bacillariophyceae 3.Teil Centrales, Fragilariaceae, Eunotiaceae. Bacillariophyceae, in: Gustav Fisher Verlag, J. (Ed.), Süsswasserflora von Mitteleuropa. Band 2/1.

Krammer, K., Lange-Bertalot, H., 1991a. Bacillariophyceae 3.Teil Centrales, Fragilariaceae, Fragilariaceae, Eunotiaceae, in: Gustav Fisher, J. (Ed.), Süsswasserflora von Mitteleuropa. Band 2/3.

Krammer, K., Lange-Bertalot, H., 1991b. Bacillariophyceae 4.Teil Achnantaceae. Kritische Erga“nzungen zu Navicula (Lineolatae) und Gomphonema, in: Gustav Fisher, J. (Ed.), Süsswasserflora von Mitteleuropa. Band 2/4.

Küster, H., 1994. The economic use of Abies wood as timber in central Europe during Roman times. Veg Hist Archaeobot 3, 25-32.

Lamb, H.F., Roberts, N., Leng, M.J., Barker, P.A., Benkaddour, A. and van der Kaars, S. 1999 Lake evolution in a semi-arid montane environment: response to catchment change and hydroclimatic variation. J Paleolimnol 21, 325-343. 
Lange-Bertalot, H., 2001. Diatoms of the Europe Inland waters and comparable habitats, Koenigstein.

Lotter, A., Birks, H., 1997. The separation of the influence of nutrients and climate on the varve time-series of baldeggersee, Switzerland. Aquat Sci 59, 362-375.

Luterbacher, J., García-Herrera, R., Allan, A. R., et al., 2012. A review of 2000 years of paleoclimatic evidence in the Mediterranean, in: Lionello, P., (Ed), The Climate of the Mediterranean region: from the past to the future. Elsevier, Amsterdam, pp 87-185.

Magny, M., 2004. Holocene climate variability as reflected by mid-European lake-level fluctuations and its probable impact on prehistoric human settlements. Quatern Int 113, $65-79$.

Magny, M., Gauthier, E., Vannière, B., Peyron, O., 2008. Palaeohydrological changes and human-impact history over the last millennium recorded at Lake Joux in the Jura Mountains, Switzerland. The Holocene 18, 255-265.

Martín-Puertas, C., Martínez-Ruiz, F., Jimenez Espejo, F.J., Nieto-Moreno, V., Rodrigo, M., Mata, M.P., Valero-Garcés, B.L., 2010. Late Holocene climate variability in the southwestern Mediterranean region: an integrated marine and terrestrial geochemical approach. Clim Past 6, 807-816.

Martín-Puertas, C., Valero-Garcés, B.L., Brauer, A., Mata, M.P., Delgado-Huertas, A., Dulski, P., 2009. The Iberian-Roman Humid Period (2600-1600 cal yr BP) in the Zoñar Lake varve record (Andalucía, southern Spain). Quaternary Res 71, 108-120.

Martín-Rubio, M., Rodriguez-Lazaro, J., Anadón, P., Robles, F., Utrilla, R., Vázquez, A., 2005. Factors affecting the distribution of recent lacustrine ostracoda from the 
Caicedo de Yuso-Arreo Lake (Western Ebro Basin, Spain). Palaeogeogr Palaeocl 225, $118-133$

Martínez-Díez, G., 2005. El condado de Castilla (711-1038). La historia frente a la leyenda, Valladolid.

Martínez-Torres, L.M., González-Tapia, J.R., Ramón-Lluch, R., 1992. Batimetría y propuesta de cartografía geológica del Lago de Arreo (Diapiro de Salinas de Añana, Álava). Cuadernos de Sección. Historia 20, 123-134.

Mazier, F., Galop, D., Gaillard, M.J., Rendu, C., Cugny, C., Legaz, A., Peyron, O., Buttler, A., 2009. Multidisciplinary approach to reconstructing local pastoral activities: an example from the Pyrenean Mountains (Pays Basque). The Holocene 19, 171-188.

Medeanic, S., Jankovská, V., Dillenburg, S.R., 2003. The implication of green algae (Chlorophyta) for palaeoecological reconstruction of the Holocene lagoon system in the Tramandaí Lagoon region, Rio Grande do Sul, Brazil. Acta Paleoebot 43, 113-123.

Morellón, M., Pérez-Sanz, A., Corella, J.P., Büntgen, U., Catalán, J., GonzálezSampériz, P., González-Trueba, J.J., López-Sáez, J.A., Moreno, A., Pla-Rabes, S., SazSánchez, M.A., Scussolini, P., Serrano, E., Steinhilber, F., Stefanova, V., VegasVilarrúbia, T., Valero-Garcés, B., 2012. A multi-proxy perspective on millennium-long climate variability in the Southern Pyrenees. Clim Past 8, 683-700.

Morellón, M., Valero-Garcés, B., González-Sampériz, P., Vegas-Vilarrúbia, T., Rubio, E., Rieradevall, M., Delgado-Huertas, A., Mata, P., Romero, Ó., Engstrom, D., LópezVicente, M., Navas, A., Soto, J., 2011. Climate changes and human activities recorded in the sediments of Lake Estanya (NE Spain) during the Medieval Warm Period and 
Little Ice Age. J Paleolimnol 46, 423-452.

Morellón, M., Valero-Garcés, B., Moreno, A., González-Sampériz, P., Mata, P., Romero, O., Maestro, M., Navas, A., 2008. Holocene palaeohydrology and climate variability in northeastern Spain: The sedimentary record of Lake Estanya (Pre-Pyrenean range). Quatern Int 181, 15-31.

Moreno, A., Pérez, A., Frigola, J., Nieto-Moreno, V., Rodrigo-Gámiz, M., Martrat, B., González-Sampériz, P., Morellón, M., Martín-Puertas, C., Corella, J.P., Belmonte, Á., Sancho, C., Cacho, I., Herrera, G., Canals, M., Grimalt, J.O., Jiménez-Espejo, F., Martínez-Ruiz, F., Vegas-Vilarrúbia, T., Valero-Garcés, B.L., 2012. The Medieval Climate Anomaly in the Iberian Peninsula reconstructed from marine and lake records. Quaternary Sci Rev 43, 16-32.

Ninyerola, M., Pons, X., Roure, J.M., 2005. Atlas Climático Digital de la Península Ibérica. Metodología y aplicaciones en bioclimatología y geobotánica. Universidad Autónoma de Barcelona, Bellaterra, Spain.

Noren, A.J., Bierman, P.R., Steig, E.J., Lini, A., Southon, J., 2002. Millennial-scale storminess variability in the northeast United States during the Holocene epoch. Nature $419,821-824$

Pastor Díaz de Garayo, E., 2004. Castilla en el tránsito de la antigüedad al feudalismo. Juan de Castilla y León. Valladolid.

Peinado Lorca, M., Rivas-Martínez, S., 1987. La vegetación de España. Servicio de Publicaciones de la Universidad de Alcalá, Alcalá de Henares.

Peñalba, M.C., 1989. Dinamique de vegetation Tardiglaciaire et Holocene du cente- 
nord de l'Espagne d'apres l'analyse pollinique., Paléoécologie par. L'université d’AixMarseille III, Marseille.

Pérez Sanz, A., González Sampériz, P., Valero-Garcés, B.L., Moreno, A., Morellón, M., Sancho, C., Belmonte, A., Gil Romera, G., Sevilla, M., Navas Izquierdo, A., 2011. Climate and human activity in the vegetation dynamics of Central Pyrenees during the last 2000 years: the Basa de la Mora record (Cotiella Massif). Zubía 23, 17-38.

Plata Montero, A., 2008. Génesis de una villa medieval. Arqueología, paisaje y arquitectura del valle salado de Añana (Álava). Universidad del País Vasco, VitoriaGasteiz

Reimer, P.J., Baillie, M.G.L., Bard, E., et al., 2009. IntCal09 and Marine09 radiocarbon age calibration curves, 0-50,000 years CAL BP. Radiocarbon 51, 1111-1150.

Reyes, J.C., 1998. Los arrieros de la sal: el transporte de la sal y su impacto en la economía local de Colima durante el Virreinato, in: Reyes, J.C. (Ed.), La Sal en México, Universidad de Colima, México.

Rico, E., Chicote, A., González, M.E., Montes, C., 1995. Batimetría y análisis morfométrico del lago de Arreo (N. España). Limnética 11 (1), 55-58.

Riera, S., López-Sáez, J.A., Julià, R., 2006. Lake responses to historical land use changes in northern Spain: The contribution of non-pollen palynomorphs in a multiproxy study. Rev Palaeobot Palyno 141, 127-137.

Riera, S., Wansard, G., Julia, R., 2004. 2000-year environmental history of a karstic lake in the Mediterranean Pre-Pyrenees: the Estanya lakes (Spain). Catena 55, 293-324. 
Rull, V., González-Sampériz, P., Corella, J., Morellón, M., Giralt, S., 2011. Vegetation changes in the southern Pyrenean flank during the last millennium in relation to climate and human activities: the Montcortès lacustrine record. J Paleolimnol 46, 387-404.

Schnurrenberger, D., Russell, J., Kelts, K., 2003. Classification of lacustrine sediments based on sedimentary components. J Paleolimnol 29, 141-154.

Thorndycraft, V.R., Benito, G., 2006. Late Holocene fluvial chronology of Spain: The role of climatic variability and human impact. Catena 66, 34-41.

Tinner, W., Hu, F.S., 2003. Size parameters, size-class distribution and area-number relationship of microscopic charcoal: relevance for fire reconstruction. The Holocene $13,499-505$.

Valero-Garcés, B.L., González-Sampériz, P., Navas, A., Machín, J., Delgado-Huertas, A., Peña-Monné, J.L., Sancho-Marcén, C., Stevenson, T., Davis, B., 2004. Paleohydrological fluctuations and steppe vegetation during the last glacial maximum in the central Ebro valley (NE Spain). Quaternary Int 122, 43-55.

Valero-Garcés, B.L., Navas, A., Machín, J., Stevenson, T., Davis, B., 2000. Responses of a saline lake ecosystem in a semiaric region to irrigation and climate variability. Ambio 29, 344-350.

Van Dam, H., Mertens, A., Sinkeldam, J., 1994. A coded checklist and ecological indicator values of freshwater diatoms from The Netherlands. Aquat Ecol 28, 117-133.

Van Geel, B., Coope, G.R., Van Der Hammen, T., 1989. Palaeoecology and stratigraphy of the lateglacial type section at Usselo (the Netherlands). Rev Palaeobot Palyno 60, 25- 
Villanueva Aranguren, J.A., 2007. Comunidad Autónoma del País Vasco/Euskadi, Álava/Araba, Tercer Inventario Forestal Nacional 1997-2007. Ministerio de Medio Ambiente, Madrid.

Williams, E., 2010. Salt Production and Trade in Ancient Mesoamerica, in: Staller, J., Carrasco, M. (Eds.), Pre-Columbian Foodways. Springer New York, pp. 175-190.

Zanni, M., Ravazzi, C., 2007. Description and differentiation of Pseudolarix amabilis pollen Palaeoecological implications and new identification key to fresh bisaccate pollen. Rev Palaeobot Palyno 145, 35-75.

Zolitschka, B., 2007. Varved lake sediments, in: Elias, S.A. (Ed.), Encyclopedia of Quaternary Science. Elsevier, Amsterdam, pp. 3105-3114. 


\section{FIGURE CAPTIONS}

Figure 1. Location map of Lake Arreo: (1a) Map of mean annual rainfall in the IP (Ninyerola et al., 2005) and geographical location of the study area. (1b) Detailed geological map of the Lake Arreo and the Añana salt diapir. (1c) Bathymetric map of Lake Arreo and core location. (1d) Vegetation map based on CORINE land cover 2000 (EEA, 2000) and the Spanish National Forest Inventory (Villanueva Aranguren, 2007).

Figure 2. Sedimentary facies and lithostratigraphic units and correlation of Arreo cores. Continuous and noncontinuous lines represent the correlation between the limits of the main sedimentary units and subunits respectively. Red dashed line shows the correlation between the shallow-water and deep-water cores. Asterisks indicate the location of radiocarbon dates shown in Table 1.

Figure 3. Chronological model of a) deep-water core ARR04-1A-1K and b) shallowwater core ARR04-2A-1K based on mixed effect regression function (Heegaard et al., 2005) of $12 \mathrm{AMS}{ }^{14} \mathrm{C}$ dates. The continuous lines represent the age-depth function, and the dashed lines display the standard deviation values.

Figure 4. Core images, sedimentary facies, elemental composition (TIC, TOC, C/N ratio), mineralogy and selected XRF profiles for deep-water ARR04-1A-1K (top) and shallow-water ARR04-2A-1K (bottom) cores. From left to right: MS: Magnetic susceptibility; TIC: Total Inorganic Carbon; TOC: Total Organic Carbon; Qz+Plag: Quartz+plagioclase; Cc: Calcite; Gy: Gypsum; Py: Pyrite; Ca/Ti: Calcium/Titanium ratio; Sr/Ca: Strontium/Calcium ratio. Facies legend is shown in Figure 2.

Figure 5. Pollen diagram of selected pollen taxa diagram for the a) deep-water core ARR04-1A-1K and b) shallow-water core ARR04-2A-1K with lithostratigraphical units 1 to 5 (in core ARR04-1A-1K) and A to D (in core ARR04-2A-1K) and local pollen 
zones (LAPZ) 1 to 5 in both cores. Pinus sp includes pollen of P. sylvestris and P. nigra. The pollen type deciduous Quercus includes $Q$. pyrenaica, $Q$. faginea, $Q$. robur, and $Q$. petrea. Evergreen Quercus includes pollen of $Q$. ilex. Cultivated taxa include Triticum/Avena, Secale, Cerealia, Cannabis-type, and Polygonum aviculare-type. Ruderals include Artemisia, Chenopodiaceae, Plantago major, P. media, and Urtica. Meadows and pastures include Aster-type, Cirsium, Chichorioideae, Apiaceae, Heracleum, Campanula-type, Filipendula, Potentilla, Gallium-type, Lathyrus, Trifolium-type, Lotus-type, Ranunculaceae, Ranunculus acris-type, Hypericum, Lotustype, Rumex acetosa, R. acetosella, Plantago lanceolata. Hygrophytes include Sparganium, Potamogetom, Utricularia, Myriophyllum and Lemna.

Figure 6. Selected taxa ( $>5 \%$ relative abundance) of the diatom record from ARR041A-1K (top) and ARR04-2A-1K (bottom) cores. P/B ratio is based on the total sum of diatom taxa. Sedimentary units are also indicated.

Figure 7. Synthesis diagram showing the resumed information from the sedimentary facies, pollen and diatom zones, limnological stages, historical records and paleohydrological reconstruction from Lake Arreo.

Figure 8. Paleohydrological evolution of Lake Arreo record during the last $2600 \mathrm{Cal}$. yr based on selected proxies and main vegetation and land uses changes in the area. Comparison with Lake Estanya (Morellón et al., 2008; 2011) paleosalinity record and Lake Montcortès paleotemperature record (Corella et al., 2012). 
a)

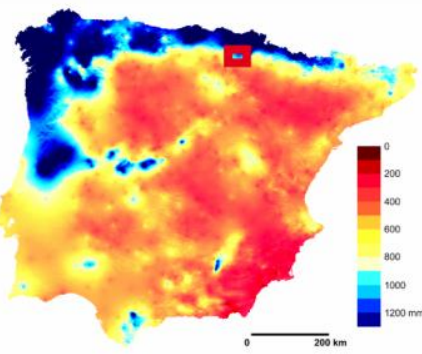

(6)

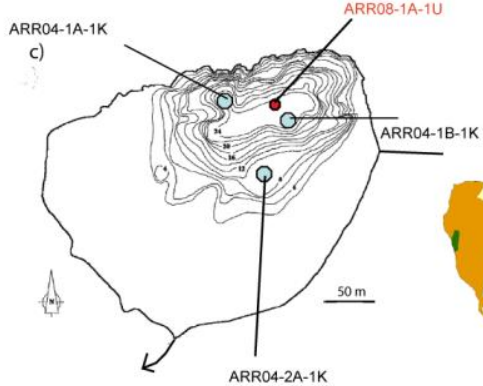

b)

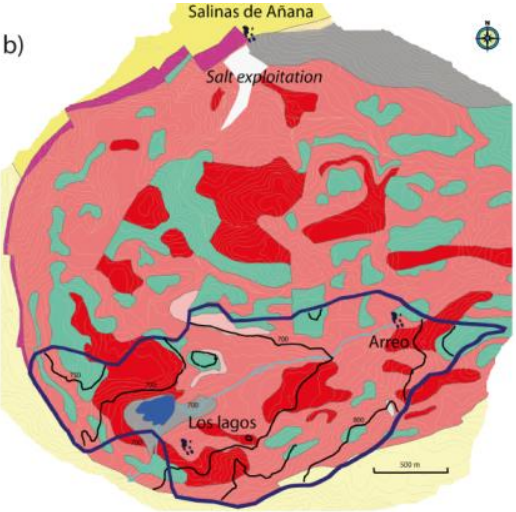

d)

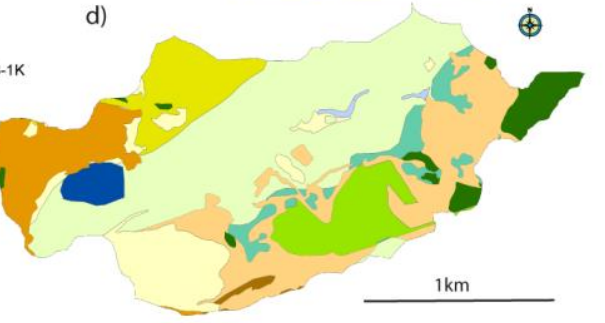

$\dot{\theta}$

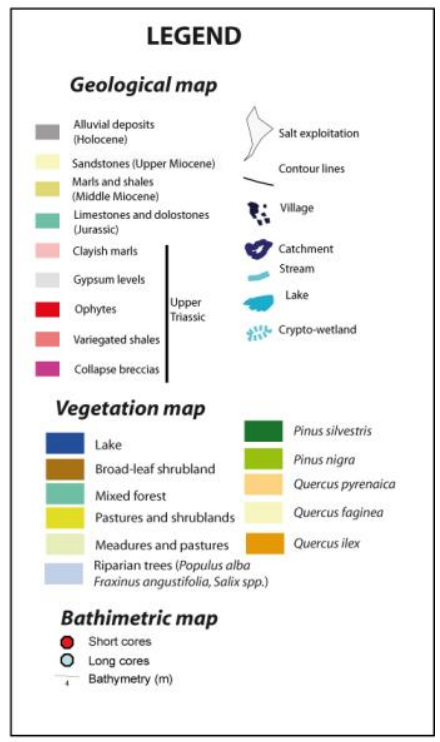




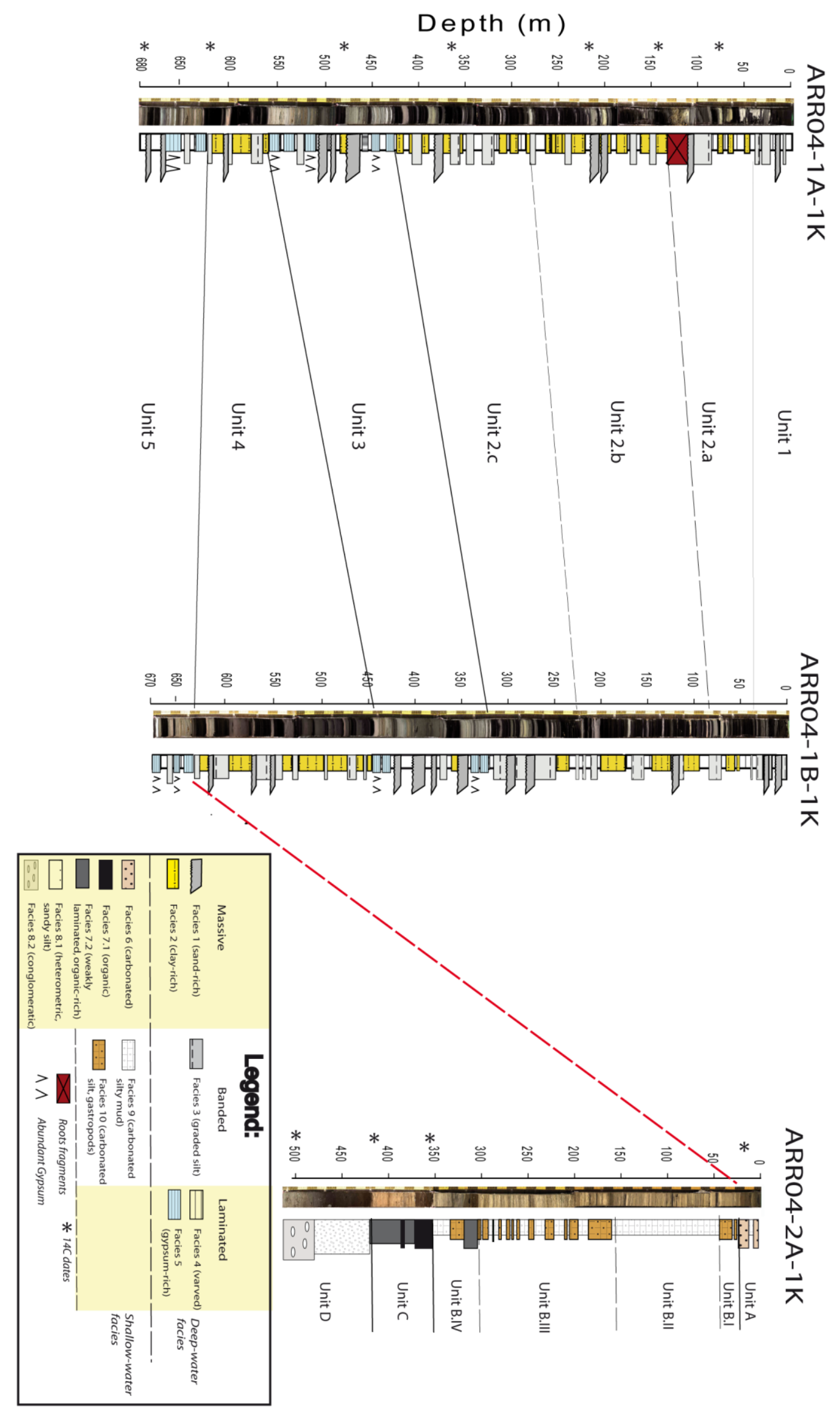


Age (AD/BC)

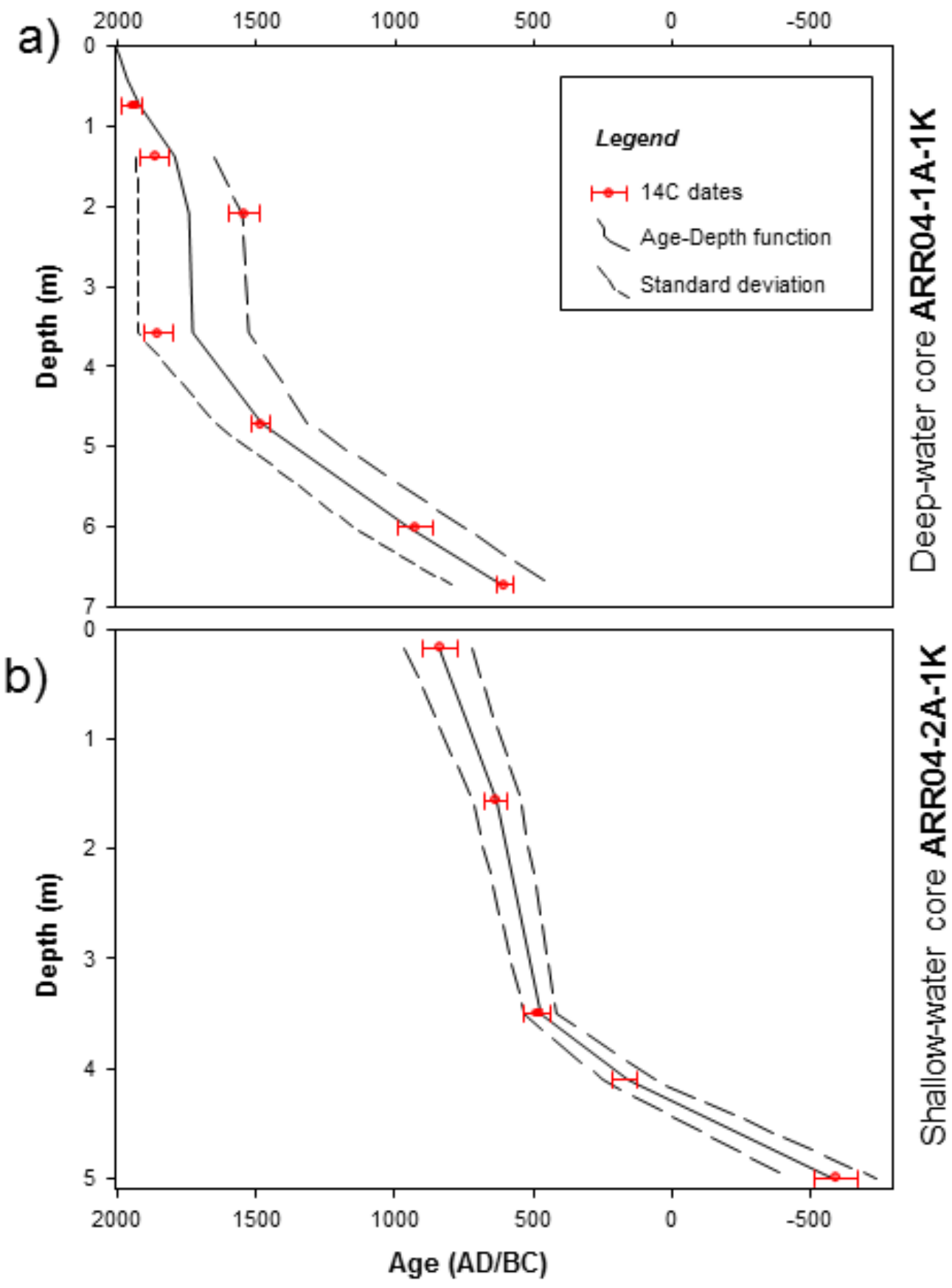




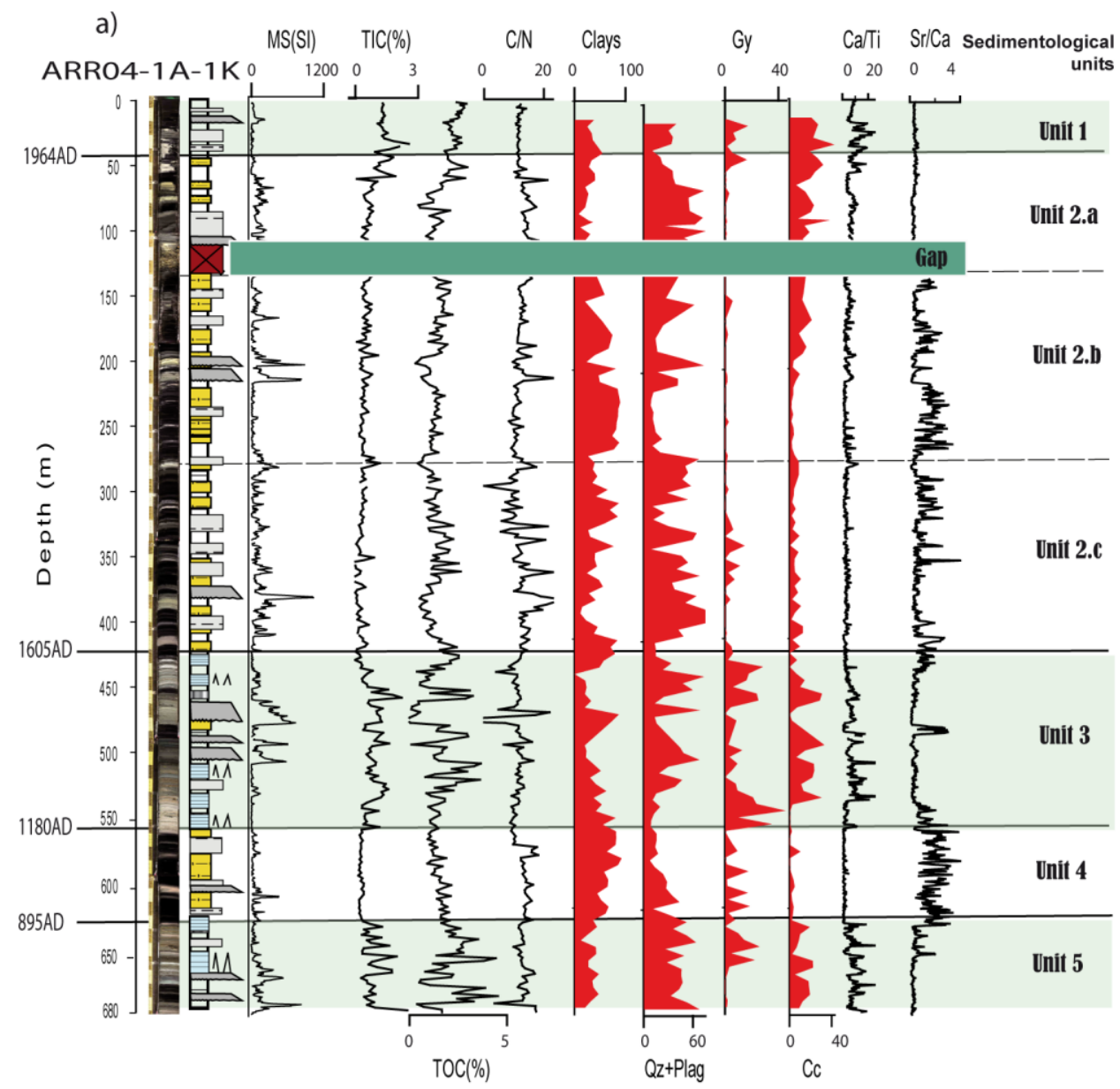

b) $\quad \mathrm{MS}(\mathrm{SI}) \quad \mathrm{TIC}(\%) \quad \mathrm{CIN} \quad$ Clays $\quad$ Gy $\quad \mathrm{Ca} / \mathrm{Ti} \quad \mathrm{Sr} / \mathrm{Ca}$

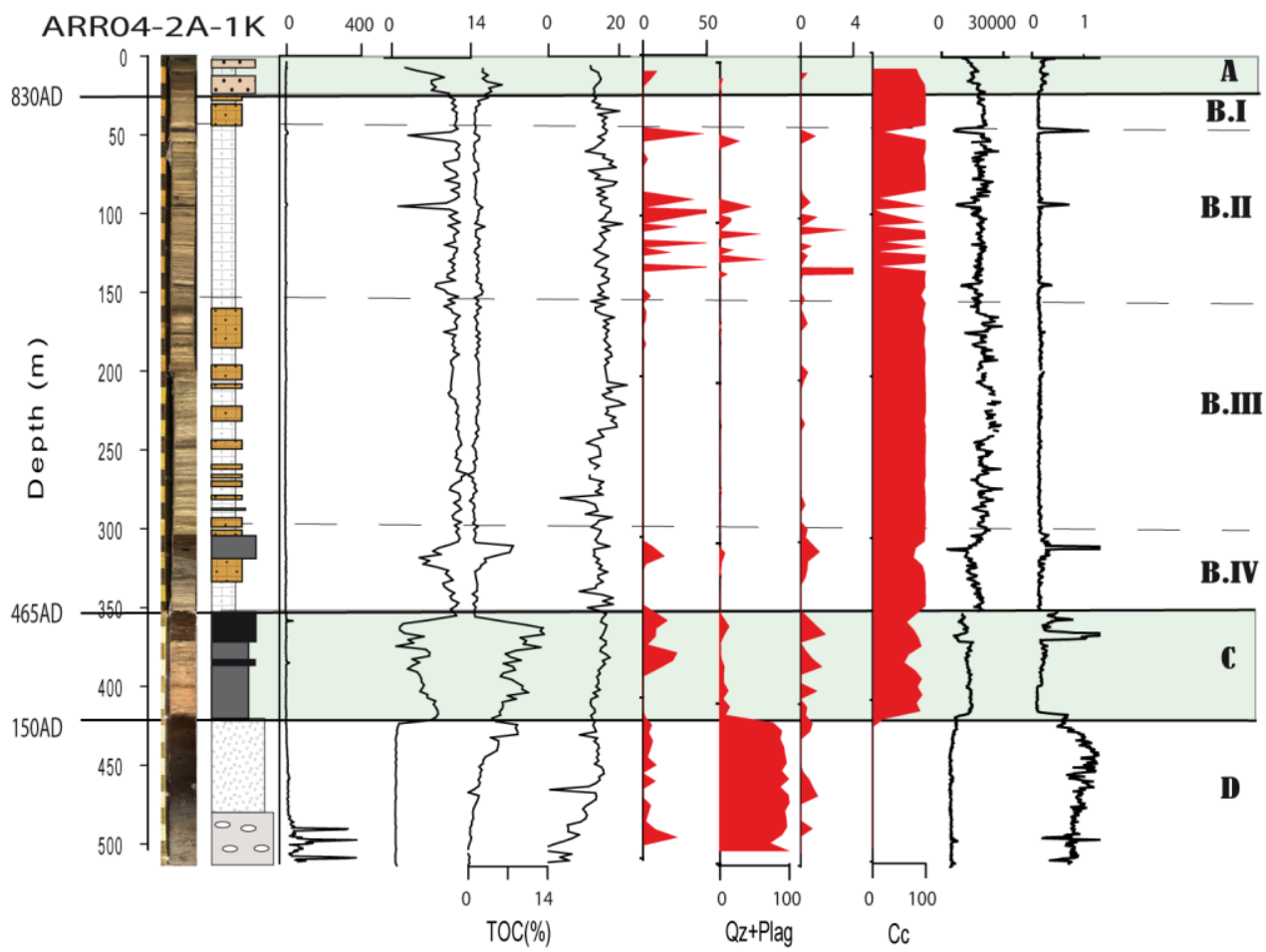



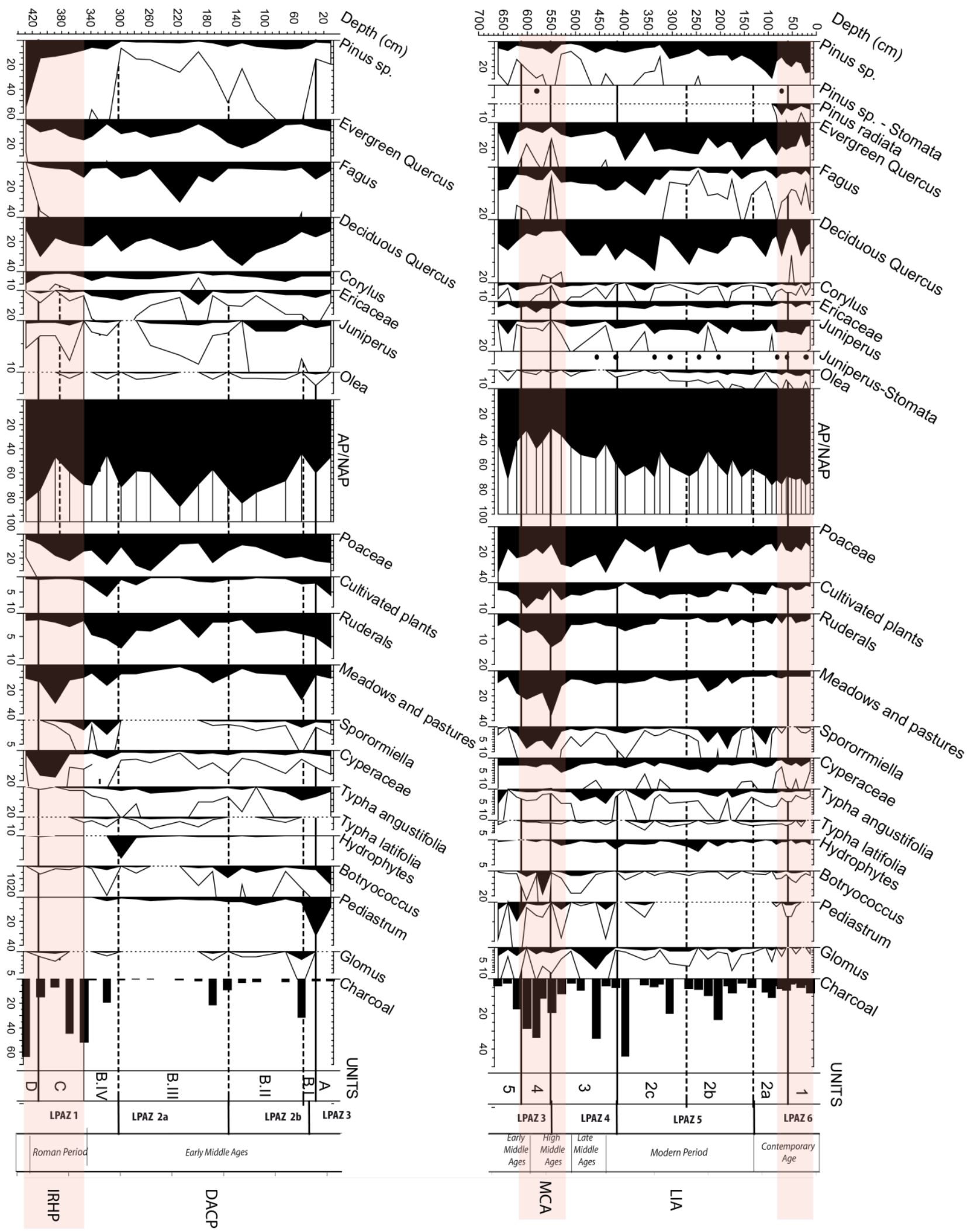

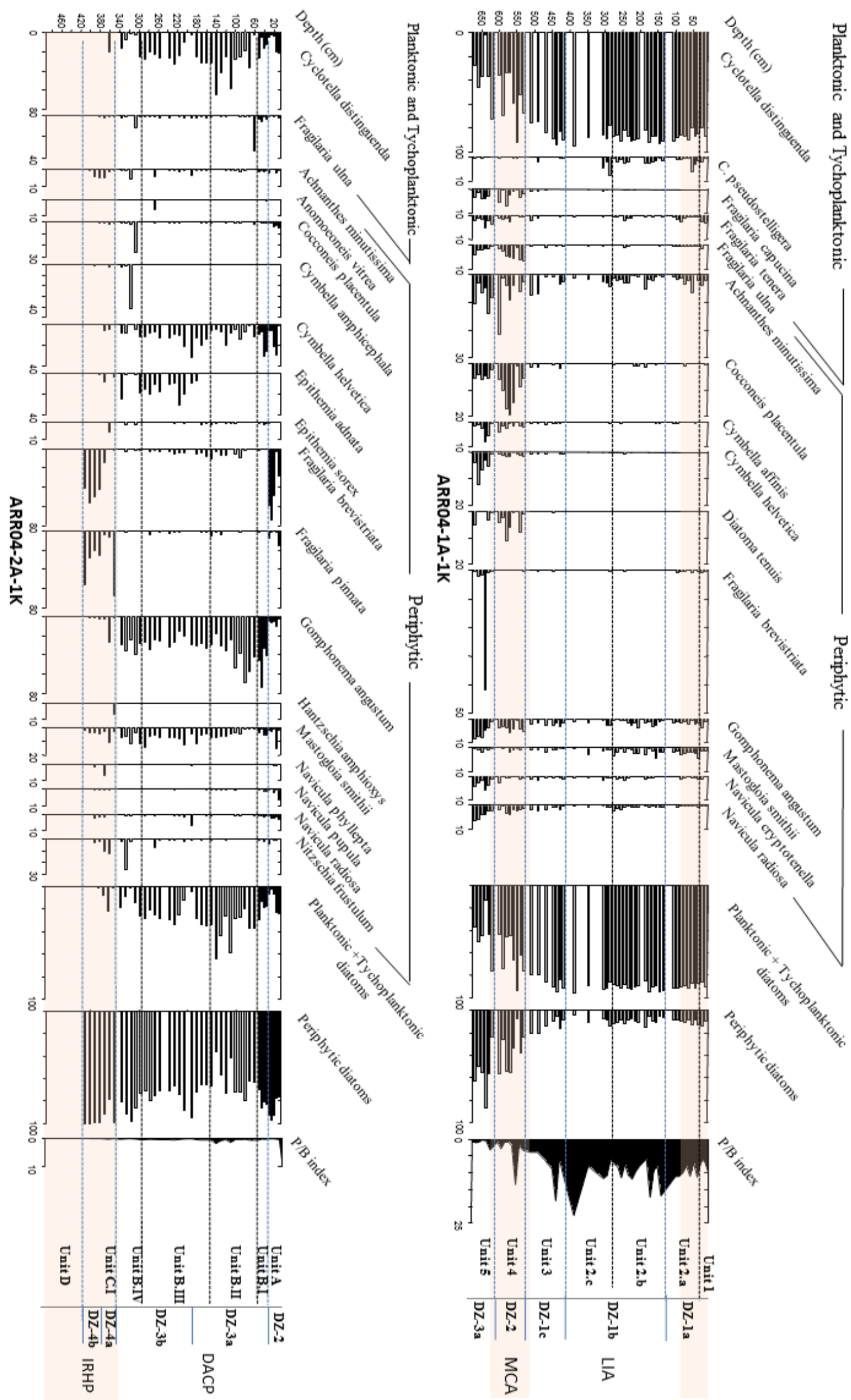


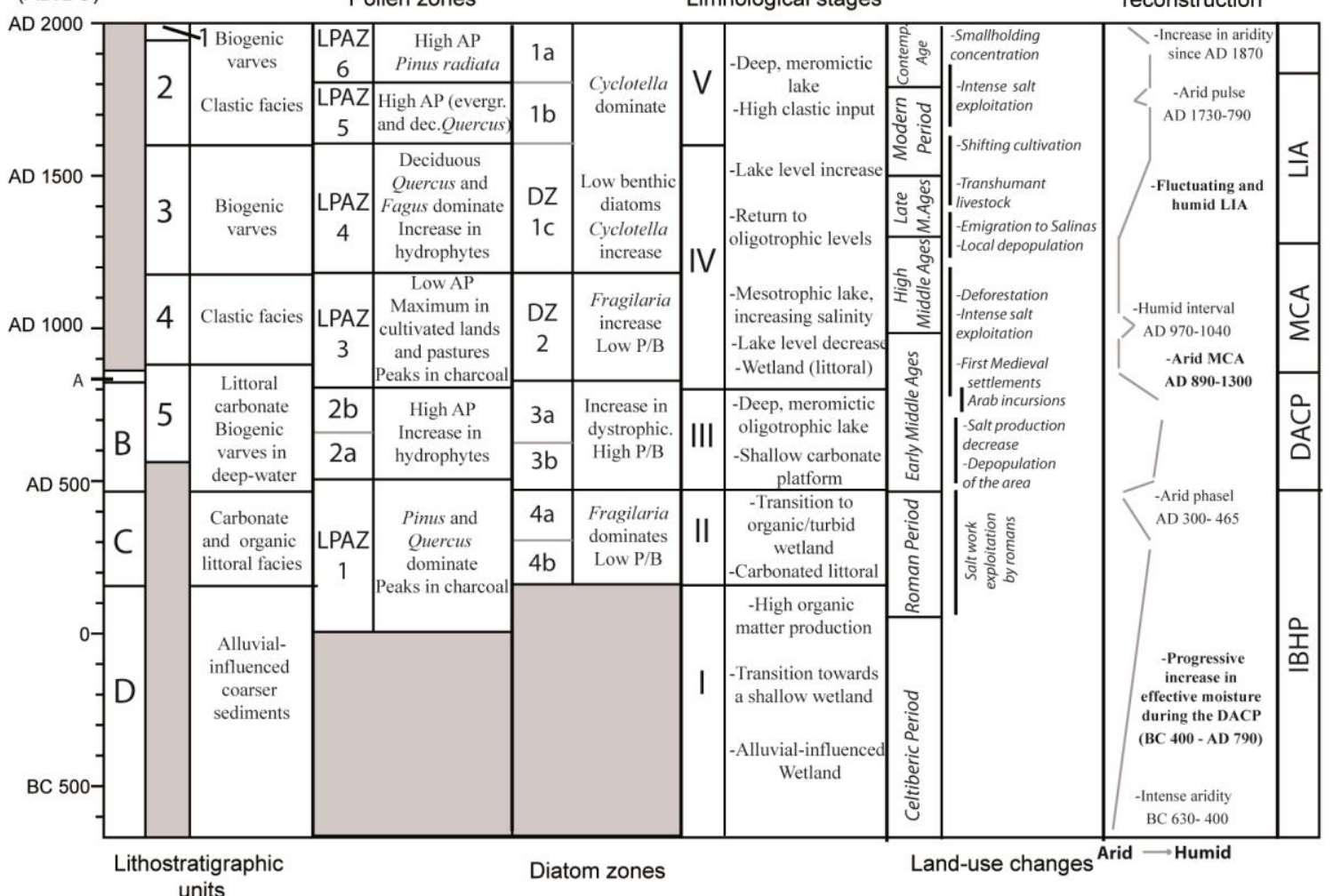




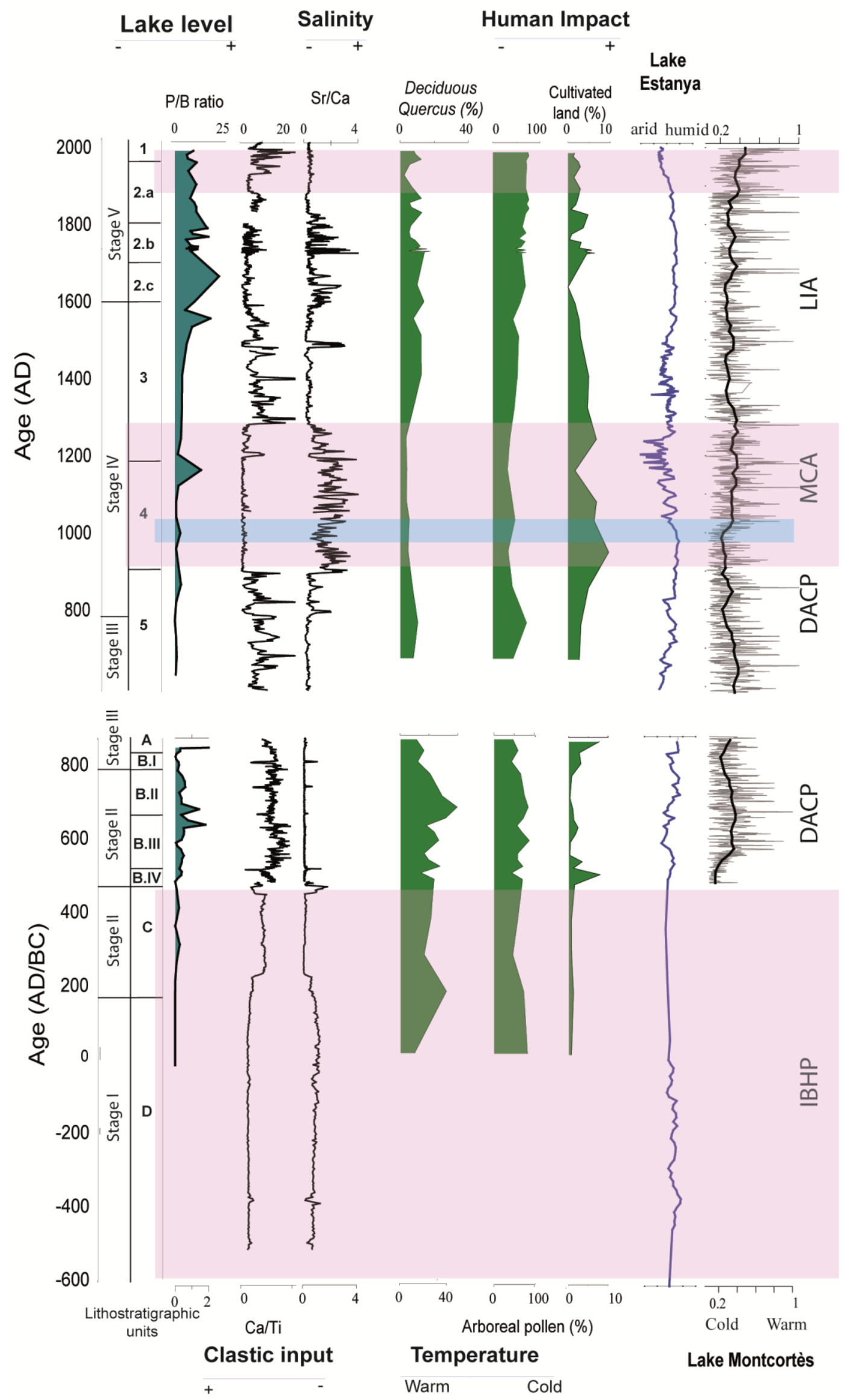




\section{TABLES}

\begin{tabular}{|c|c|c|c|c|}
\hline \multirow{2}{*}{ Parameters } & \multicolumn{4}{|c|}{ Value } \\
\hline & Units & Minimum & & Maximum \\
\hline Elevation & $\mathrm{m}$ & & 657 & \\
\hline Lake surface & $\mathrm{Ha}$ & & 6.57 & \\
\hline Catchment area & $\mathrm{Ha}$ & & 491.5 & \\
\hline Max. depth & $\mathrm{m}$ & & 24.8 & \\
\hline Volume: & $\mathrm{Hm}^{3}$ & & 0.35 & \\
\hline Temperature & ${ }^{\circ} \mathrm{C}$ & 1.4 & & 27.4 \\
\hline Oxygen content & $\mathrm{mg} / \mathrm{l}$ & 0 & & 18.9 \\
\hline Conductivity & $\mu \mathrm{S} / \mathrm{cm}$ & 703 & & 1410 \\
\hline $\mathrm{pH}$ & & 5.13 & & 8.98 \\
\hline Alkalinity & meq/l & 1.3 & & 5.42 \\
\hline $\mathrm{PO}_{4}$ & $\mu \mathrm{gP}-\mathrm{PO}_{4} / \mathrm{l}$ & 0.1 & & 31.9 \\
\hline Total P & $\mu \mathrm{g} / 1$ & 5.8 & & 167.8 \\
\hline & $\mu \mathrm{gN}-$ & & & \\
\hline NO3 & $\mathrm{NO}_{3} / \mathrm{l}$ & 8.1 & & 2370 \\
\hline Total N & $\mu \mathrm{g} / 1$ & 313 & & 6550 \\
\hline Chlorophyll_a & $\mu \mathrm{g} / 1$ & 0.2 & & 245.5 \\
\hline Secchi disk & $\mathrm{m}$ & 1.33 & & 8.13 \\
\hline
\end{tabular}

Table 1. General limnological and hydrological characteristics from Lake Arreo (December 2001-August 2012) 


\begin{tabular}{|c|c|c|c|c|c|c|}
\hline $\begin{array}{l}\text { Core Depth } \\
\text { (m) }\end{array}$ & Lab code & Material & ${ }^{14} \mathrm{C}$ ages & $\begin{array}{l}\text { Cal years } B P \\
\text { (16 range) }\end{array}$ & AD years & Unit \\
\hline \multicolumn{7}{|c|}{ ARR04-1A-1K } \\
\hline $0.74 \mathrm{~m}$ & CNA145 & Macrorest (root) & Modern & Modern & Post 1950 & 2 \\
\hline $1.38 \mathrm{~m}$ & CNA146 & Macrorest (phragmites) & $80 \pm 60$ & $85 \pm 55$ & $1865 \pm 55$ & 2 \\
\hline $2.09 \mathrm{~m}$ & CNA147 & Macrorest & $330 \pm 70$ & $405 \pm 55$ & $1545 \pm 55$ & 2 \\
\hline $3.58 \mathrm{~m}$ & CNA148 & Macrorest (phragmites) & $80 \pm 60$ & $85 \pm 55$ & $1865 \pm 55$ & 2 \\
\hline $4.72 \mathrm{~m}$ & POZ33481 & Terrestrial wood+charcoal & $370 \pm 35$ & $465 \pm 35$ & $1485 \pm 35$ & 2 \\
\hline $5.015 \mathrm{~m}^{*}$ & POZ33482 & Hygrophyte* & $145 \pm 30^{*}$ & $200 \pm 25^{*}$ & $1750 \pm 25^{*}$ & 3 \\
\hline $5.7 \mathrm{~m}^{*}$ & CNA149 & Macrorest* & $130 \pm 70^{*}$ & $105 \pm 45^{*}$ & $1845 \pm 45^{*}$ & 4 \\
\hline $6.01 \mathrm{~m}$ & CNA150 & Macrorest (terrestrial plant) & $1130 \pm 70$ & $1025 \pm 65$ & $925 \pm 65$ & 4 \\
\hline $6.73 \mathrm{~m}$ & POZ33484 & Hygrophyte+charcoal & $1465 \pm 35$ & $1345 \pm 30$ & $605 \pm 30$ & 5 \\
\hline \multicolumn{7}{|c|}{ ARR04-2A-1K } \\
\hline $0.17 \mathrm{~m}$ & CNA151 & Macrorest & $1170 \pm 70$ & $1110 \pm 60$ & $840 \pm 60$ & A \\
\hline $1.56 \mathrm{~m}$ & CNA152 & Macrorest & $1400 \pm 60$ & $1320 \pm 40$ & $630 \pm 40$ & B \\
\hline $3.05 \mathrm{~m}^{*}$ & CNA153 & $\begin{array}{l}\text { Macrorest (terrestrial } \\
\text { plant)* }\end{array}$ & $1140 \pm 60^{*}$ & $1030 \pm 60^{*}$ & $920 \pm 60^{*}$ & B \\
\hline $3.065 \mathrm{~m}^{*}$ & POZ33485 & $\begin{array}{l}\text { Hygrophyte+Terrestrial } \\
\text { wood* }\end{array}$ & $1380 \pm 35^{*}$ & $1300 \pm 20^{*}$ & $650 \pm 20 *$ & B \\
\hline $3.5 \mathrm{~m}$ & POZ33486 & Seed capsule & $1550 \pm 35$ & $1465 \pm 50$ & $485 \pm 50$ & B \\
\hline $4.1 \mathrm{~m}$ & POZ33487 & Hygrophyte & $1860 \pm 40$ & $1780 \pm 45$ & $170 \pm 45$ & $\mathrm{C}$ \\
\hline $5 \mathrm{~m}$ & CNA155 & Macrorest (terrestrial plant) & $2480 \pm 70$ & $2545 \pm 80$ & BC $595 \pm 80$ & $\mathrm{D}$ \\
\hline
\end{tabular}

Table 2. Radiocarbon dates obtained in the Lake Arreo ARR04-1A-1K and ARR04-2A-1K cores. The ages labelled with an asterisk have not been included in the age model. 